\title{
Description and evaluation of a new four-mode version of the Modal Aerosol Module (MAM4) within version 5.3 of the Community Atmosphere Model
}

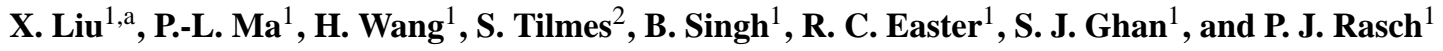 \\ ${ }^{1}$ Atmospheric Sciences and Global Change Division, Pacific Northwest National Laboratory, Richland, Washington, USA \\ ${ }^{2}$ National Center for Atmospheric Research, Boulder, Colorado, USA \\ ${ }^{a}$ now at: Department of Atmospheric Science, University of Wyoming, Laramie, Wyoming, USA
}

Correspondence to: X. Liu (xliu6@uwyo.edu)

Received: 8 July 2015 - Published in Geosci. Model Dev. Discuss.: 29 September 2015

Revised: 8 January 2016 - Accepted: 20 January 2016 - Published: 8 February 2016

\begin{abstract}
Atmospheric carbonaceous aerosols play an important role in the climate system by influencing the Earth's radiation budgets and modifying the cloud properties. Despite the importance, their representations in large-scale atmospheric models are still crude, which can influence model simulated burden, lifetime, physical, chemical and optical properties, and the climate forcing of carbonaceous aerosols. In this study, we improve the current three-mode version of the Modal Aerosol Module (MAM3) in the Community Atmosphere Model version 5 (CAM5) by introducing an additional primary carbon mode to explicitly account for the microphysical ageing of primary carbonaceous aerosols in the atmosphere. Compared to MAM3, the four-mode version of MAM (MAM4) significantly increases the column burdens of primary particulate organic matter (POM) and black carbon (BC) by up to $40 \%$ in many remote regions, where in-cloud scavenging plays an important role in determining the aerosol concentrations. Differences in the column burdens for other types of aerosol (e.g., sulfate, secondary organic aerosols, mineral dust, sea salt) are less than $1 \%$. Evaluating the MAM4 simulation against in situ surface and aircraft observations, we find that MAM4 significantly improves the simulation of seasonal variation of near-surface $\mathrm{BC}$ concentrations in the polar regions, by increasing the $\mathrm{BC}$ concentrations in all seasons and particularly in cold seasons. However, it exacerbates the overestimation of modeled $\mathrm{BC}$ concentrations in the upper troposphere in the Pacific regions. The comparisons suggest that, to address the remaining model POM and BC biases, future improvements are re-
\end{abstract}

quired related to (1) in-cloud scavenging and vertical transport in convective clouds and (2) emissions of anthropogenic and biomass burning aerosols.

\section{Introduction}

Atmospheric aerosols from natural and anthropogenic sources play an important role in the climate system. In spite of extensive studies in the past several decades, radiative forcing of atmospheric aerosols is still associated with large uncertainties according to the Intergovernmental Panel of Climate Change Assessment Reports (Forster et al., 2007; Myhre et al., 2013). The large uncertainty of aerosol radiative forcing among global climate models (GCMs) reflects the diversity in treatments of aerosol properties and processes in GCMs. A multitude of processes influence aerosols in the atmosphere, which include emission, nucleation, coagulation, gas-phase and aqueous chemical reactions, dry deposition, gravitational settling, and wet scavenging by clouds and precipitation. These processes determine the burden and lifetime of aerosols, particle size distribution, mixing state, and thus the radiative forcing of aerosols on the climate (Textor et al., 2006; Schulz et al., 2006; Quaas et al., 2009). Furthermore, the burden and size distribution of aerosols control their surface area density and thereby influence heterogeneous chemistry, which can then induce chemical effects such as extended methane lifetime (Tilmes et al., 2015). 
Primary carbonaceous aerosols are produced from the incomplete combustion of fossil and biomass fuels, and are one of the most important types of aerosol in the atmosphere. Most models tend to speciate the mass of carbonaceous aerosols into a light-absorbing component (black carbon, BC) and a purely scattering component (particulate organic matter, POM). BC has a strong warming effect, second only to carbon dioxide, on the climate system, with the industrial-era (1750 to 2005) direct radiative forcing of $+0.71 \mathrm{~W} \mathrm{~m}^{-2}$ with $90 \%$ uncertainty bounds of $(+0.08$, $+1.27) \mathrm{W} \mathrm{m}^{-2}$ (Bond et al., 2013). Once emitted into the atmosphere, $\mathrm{BC}$ can be transported to the polar regions far from distant sources (e.g., Bian et al., 2013; Wang et al., 2013), and deposited on the surface of snow and sea ice by dry and wet deposition (e.g., Jiao et al., 2014). BC-in-snow can absorb solar radiation efficiently, heat the snowpack, and induce a positive feedback on the surface albedo (Hansen and Nazarenko, 2004; Jacobson, 2004; Hansen et al., 2005; Flanner et al., 2007, 2009, 2012).

Although climatologically important, BC is still not simulated well by GCMs in many regions. For example, high bias of $\mathrm{BC}$ concentrations in the upper troposphere in the tropics and subtropics exists in almost all the global models participating in the AeroCom Phase I and Phase II intercomparison (Koch et al., 2009; Schwarz et al., 2010; Samset et al., 2014), while low $\mathrm{BC}$ bias in the lower atmosphere by over a factor of 10 exists in the polar regions. The aerosol absorption optical depth also tends to be biased low in GCMs compared to satellite observations (Koch et al., 2009), although it compares better to ground-based Sun photometers (Kinne et al., 2006). Note that differences between satellite retrievals and groundbased observations can be attributed to collocation/sampling and/or retrieval errors, but require further investigation.

Freshly emitted carbonaceous aerosols are usually hydrophobic, especially those emitted from fossil fuel combustion. They cannot serve as cloud condensation nuclei $(\mathrm{CCN})$. However, these particles can experience physical and chemical ageing in the atmosphere. Condensation and coagulation processes coat carbonaceous particles with soluble species (e.g., sulfate), which enables them to nucleate cloud droplets. Inside clouds, once these cloud droplets are converted to raindrops via various rain-production processes, carbonaceous aerosols in the cloud droplets can be removed from the atmosphere when raindrops fall to the ground (i.e., the so-called nucleation scavenging). Meanwhile, when BC is internally mixed with non-absorbing soluble materials, its absorption of sunlight can be enhanced compared to the external mixing treatment, as the soluble materials act as a lens (for the shell-core representation of particle morphology) (Jacobson 2001, 2003) or expand the cross section of the absorbing material (for the volume mixing representation) (Adachi et al., 2010). Therefore, in order to simulate aerosol concentration, spatial distribution, lifetime, and climate forcing correctly, a physically based representation of atmospheric processes af- fecting the mixing state of carbonaceous aerosols is needed in the models.

The simplest treatment of carbonaceous aerosols, e.g., bulk models, assumes that carbonaceous aerosols and other aerosol types (e.g., sulfate) are externally mixed (i.e., different components do not coexist in the same particle), and often uses a prescribed timescale (1-2 days) for the ageing of primary carbonaceous aerosols from the hydrophobic to hydrophilic state (Cooke and Wilson, 1996; Tie et al., 2005). More sophisticated treatments, e.g., modal and sectional aerosol models, predict the aerosol size distribution, and determine the mixing state of carbonaceous aerosols by the coating thickness of soluble materials such as sulfate and organics on these aerosols (e.g., Liu et al., 2005; Stier et al., 2005; Spracklen et al., 2005; Bauer et al., 2008). Even more advanced aerosol treatments explicitly resolve the mixing state by tracking the composition of individual particles in a population of different aerosol types (Riemer et al., 2009). However, this approach is computationally prohibitive for global models.

Liu et al. (2012) developed a Modal Aerosol Module (MAM) for the Community Atmosphere Model version 5 (CAM5). The seven-mode version of MAM (MAM7) provides the benchmark simulation of aerosols in CAM5. In MAM7, the microphysical ageing of primary carbonaceous aerosols from the primary carbon mode to the accumulation mode through condensation and coagulation is explicitly treated, with a threshold coating thickness of three monolayers of sulfate. For the sake of computational efficiency, a simplified three-mode version of MAM (MAM3) was developed for use as the default in CAM5. MAM3 is based on the MAM7 by merging the primary carbon mode with the accumulation mode, and assuming instantaneous internal mixing of primary carbonaceous aerosols with secondary aerosols (e.g., sulfate and secondary organic aerosols).

CAM5 with MAM3 is able to simulate many features of the observed spatial distribution of concentrations of different types of aerosol, aerosol optical depth, aerosol number and size distribution over different geographical regions of the world. However, similarly to other global models (Koch et al., 2009), CAM5 significantly underestimates the nearsurface $\mathrm{BC}$ concentrations in remote regions, e.g., in the Arctic (Liu et al., 2012; Wang et al., 2013; Ma et al., 2013a). While the underestimation of BC emission in Asia (e.g., Cohen and Wang, 2014) and in the high latitudes of the Northern Hemisphere (NH) (e.g., Stohl et al., 2013) can be an important factor, the excessively efficient scavenging of BC by liquid cloud processes (Wang et al., 2013) and the coarse horizontal resolution $(\sim 100-200 \mathrm{~km})$ of the model (Ma et al., 2014) also contribute to this model bias.

To address this low BC bias found in CAM5 with MAM3 as well as in many GCMs, without significantly increasing the computational cost, we have developed a four-mode version of MAM (MAM4) for the next generation of GCMs, including version 6 of CAM (CAM6) and the U.S. Depart- 
ment of Energy's Accelerated Climate Modeling for Energy (ACME).

In this paper, we provide a technical description and a first evaluation of MAM4. The paper is organized as follows. Section 2 describes MAM4. Section 3 introduces the sensitivity tests related to the microphysical ageing of primary carbonaceous aerosols and model horizontal resolution. Comparison of MAM4 with MAM3 and evaluation of MAM4 with observation data focusing on $\mathrm{BC}$ are given in Sect. 4. Conclusions are drawn in Sect. 5.

\section{Model description}

\subsection{CAM5}

CAM5 is the atmosphere component of the Community Earth System Model version 1 (CESM1.0) (Neale et al., 2012). Compared to its earlier versions, CAM5 is designed to simulate aerosol effects on stratiform clouds (i.e., indirect effect) through acting as $\mathrm{CCN}$ and ice nuclei (IN). Aerosol effects on convective cloud microphysics are not treated in CAM5. MAM predicts the mass mixing ratios of internally mixed aerosol species within an aerosol mode and number concentrations of aerosol in that mode (Liu et al., 2012). A two-moment stratiform cloud microphysics scheme (Morrison and Gettelman, 2008; Gettelman et al., 2010) predicts the mass and number mixing ratios of cloud liquid and cloud ice, diagnoses the mass and number mixing ratios of rain and snow, and considers the complicated conversions among the cloud hydrometeors. The nucleation (i.e., in-cloud) scavenging of aerosols in stratiform clouds is treated consistently with the droplet activation in cloud microphysics (AbdulRazzak and Ghan, 2000), by explicitly calculating aerosols in the cloud-liquid-borne state (Ghan and Easter, 2006). Aerosols can affect ice microphysics by homogeneous ice nucleation of aerosol solution droplets (e.g., sulfate aerosol) in cirrus clouds with temperatures lower than about $-37^{\circ} \mathrm{C}$ and heterogeneous ice nucleation in cirrus clouds and in mixed-phase clouds (Liu et al., 2007; Liu and Penner, 2005). However, aerosol scavenging by these ice nucleation processes is neglected in CAM5.

Other major components in CAM5 include (1) a stratiform cloud macrophysics scheme (Park et al., 2014) to estimate the cloudy volume (cloud fraction), (2) a moist turbulence scheme (Bretherton and Park, 2009) to explicitly simulate stratus-radiation-turbulence interactions, (3) a radiation scheme (Iacono et al., 2008) to more accurately treat the radiative effects of clouds and aerosol, (4) a shallow convection scheme (Park and Bretherton, 2009) to better simulate the observed spatial distribution of shallow convective activity, and (5) a modified deep convection scheme (Zhang and McFarlane, 1995) with the inclusion of sub-grid convective momentum transports (Richter and Rasch, 2008) and the updated closure (Neale et al., 2008).

\subsection{MAM in CAM5}

There are two versions of MAM available in CAM5: the default MAM3 and an optional MAM7 (Liu et al., 2012). MAM3 predicts the aerosol size distribution with three aerosol modes (Aitken, accumulation and coarse modes), while MAM7 includes seven aerosol modes (Aitken, accumulation, primary carbon, fine dust and fine sea salt, coarse dust and coarse sea salt modes). In MAM3 instantaneous ageing of primary carbonaceous particles is assumed by emitting them in the accumulation mode, while in MAM7 the ageing of the carbonaceous particles in the primary carbon mode due to the condensation of sulfuric acid $\left(\mathrm{H}_{2} \mathrm{SO}_{4}\right.$ vapor), ammonia $\left(\mathrm{NH}_{3}\right)$, and the semi-volatile organics, and the coagulation of Aitken mode particles with primary-carbon mode particles are explicitly treated. Both sea salt and dust emissions are calculated on-line and are highly sensitive to the surface wind speed. Other processes in the atmosphere affecting aerosol properties (e.g., number/mass concentration, size, density, refractive index, chemical composition) include new particle formation, gas- and aqueous-phase chemistry, dry deposition and gravitational settling, water uptake, incloud (nucleation) and below-cloud scavenging, and release from evaporated cloud and raindrops. There are 15 transported aerosol tracers in MAM3 and 31 in MAM7.

\subsection{Development of MAM4}

In this study, we developed a four-mode version of MAM (MAM4), which includes an additional primary carbon mode on top of MAM3 to explicitly treat the microphysical ageing of primary carbonaceous aerosols in the atmosphere. As in MAM7, fresh emitted POM / BC particles are put in the newly added primary carbon mode. A criterion of eight monolayers of sulfate or equivalent amount of secondary organic aerosol (SOA) with the same increase in volumeweighted hygroscopicity as sulfate is required to convert POM / BC particles in the primary carbon mode to the accumulation mode. We use a value of 0 for the hygroscopicity ( $\kappa$ parameter) of POM from all sources. This value is more representative of POM produced from fossil fuel combustion. The hygroscopicity of POM from biomass burning sources can be higher (0.06-0.30) (Liu and Wang, 2010). A non-zero hygroscopicity of POM allows in-cloud scavenging of POM / BC particles in the primary carbon mode before they are aged into the accumulation mode, and then the differences in the POM and BC concentrations between MAM3 and MAM7 are smaller (Liu et al., 2012). A separate treatment of carbonaceous aerosols emitted from fossil fuel versus biomass burning sources will be needed to seamlessly consider the different hygroscopicity of POM. The $\kappa$ value for $\mathrm{BC}$ is set to 0 to reflect its hydrophobic nature.

Similarly, the refractive index for BC-containing particles changes as the particles age. The refractive index for fresh particles is the volume mean of the refractive index of the 


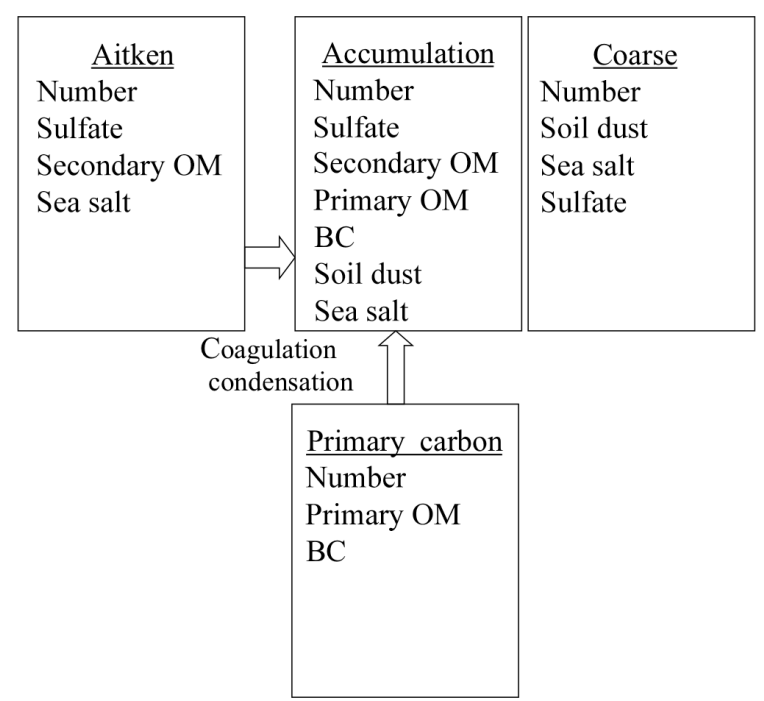

Figure 1. Schematic of aerosol modes and associated aerosol tracers in MAM4.

$\mathrm{BC}$ and POM, while the refractive index of aged particles is the volume mean of the refractive index of all components of the accumulation mode.

With the new primary carbon mode, three prognostic variables are added in MAM4 compared to MAM3: mass mixing ratios of $\mathrm{POM}$ and $\mathrm{BC}$ in the primary carbon mode and number concentration of the primary carbon mode particles, which brings the total number of aerosol tracers from 15 in MAM3 to 18 in MAM4. The other aerosol tracers and precursor gases are the same as those in MAM3. The computational cost increases by $\sim 10 \%$ for the stand-alone CAM5 (i.e., an uncoupled atmosphere-only simulation with prescribed sea surface temperatures and sea ice) with MAM4 compared to CAM5 with MAM3. As noted in Liu et al. (2012), CAM5 with MAM7 is $30 \%$ slower than CAM5 with MAM3. Figure 1 shows the schematic of aerosol modes and associated aerosol tracers in MAM4.

\section{Model configurations and experiments}

Two sets of experiments were performed using version 5.3 of CAM (CAM5.3) with the new MAM4 (hereafter CAM5MAM4), as listed in Table 1. The first set is to test the model sensitivity to the criterion of number of monolayers required for the ageing of POM / BC particles from the primary carbon mode to the accumulation mode. We conducted four experiments with the number of monolayers set to 1,2, 4 and 8, respectively. A higher monolayer criterion means that a larger sulfate or SOA coating thickness is needed to age the primary carbonaceous aerosols, and thus these particles will stay longer in the primary carbon mode before converting to the accumulation mode. As noted in Liu et al. (2012), for a non-hygroscopic particle with a $0.134 \mu \mathrm{m}$ diameter, which is the volume-mean size for $\mathrm{BC}$ / POM emissions, the critical supersaturation in the case of eight monolayers of sulfate is $0.32 \%$ based on the Köhler theory, in comparison to $0.49 \%$ in the case of three monolayers. These CAM5-MAM4 simulations were conducted for present-day (year 2000) emissions and climate conditions with freely evolving meteorological fields (e.g., winds and temperature) at $0.9^{\circ} \times 1.25^{\circ}$ ( $1^{\circ}$ hereafter) horizontal resolution for 11 years. The last $10-$ year results are used for analysis. For comparison, an additional experiment using CAM5.3 with the default MAM3 was performed for 11 years at the same $1^{\circ}$ horizontal resolution. We also conducted an experiment with MAM7, which gave BC and POM results very similar to MAM4 (figure not shown), and thus are not included in the comparison.

The second set of experiments is to test the model sensitivity to the horizontal resolution (see Table 1), since model resolution has been suggested to play an important role for the BC transport to the remote regions (Ma et al., 2013a, 2014). Four experiments were conducted at $1.9^{\circ} \times 2.5^{\circ}\left(2^{\circ}\right.$ hereafter), $1,0.5$, and $0.25^{\circ}$ using the specified dynamics (SD) configuration (also known as the nudging technique) where the model meteorology is strongly constrained by an external meteorological analysis (Ma et al., 2013a, b, 2015; Tilmes et al., 2015). To explore the behavior of MAM4 at higher horizontal resolution, we used the ECMWF Year of Tropical Convection (YOTC) high-resolution $\left(0.15^{\circ}\right)$ analysis to drive the model, while aerosol emissions are the same as that in the first set of experiments. The SD configuration has been recalibrated so that the model physics properly responds to the realistic meteorology (Ma et al., 2015). This approach facilitates the direct comparison between model simulations and field campaign measurements since the simulation of aerosol lifecycle (emission, transport, and deposition) is based on a realistic climate. These SD simulations were performed from 1 November 2008 to 1 January 2010, and the 1-year results in 2009 were used for our analysis. The eight-monolayer criterion was used in this set of experiments. In addition, by comparing the second set of experiments with the SD configuration to the first set of experiments with the free-running configuration (e.g., MAM4L8 versus MAM4R1), we can examine the effect of model meteorology on aerosol simulations. We also ran CAM5.3 with the default MAM3 at $1^{\circ}$ resolution with the $\mathrm{SD}$ configuration for comparison.

\section{Results}

\subsection{Comparison of MAM4 with MAM3}

Figure 2 shows the latitudinal and longitudinal distributions of annual mean column burdens of BC and POM from the set 1 experiments with CAM5-MAM4, in comparison with the default MAM3. BC and POM burdens have maxima in industrial regions (e.g., East Asia, Europe, and North America) and in biomass burning regions (e.g., central and south- 
Table 1. Model experiments. Set 1 experiments are to test the model sensitivity to the criterion of number of ageing monolayers, running CAM5-MAM4 in free-running simulations at a horizontal resolution of $1^{\circ}$. Set 2 experiments are to test the model sensitivity to the model horizontal resolution, running CAM5-MAM4 in specified dynamics (SD) simulations with the number of ageing monolayers set to 8. In both sets of experiments the standard CAM5.3 with MAM3 is run for the comparison.

\begin{tabular}{clccl}
\hline \multicolumn{2}{c}{ Experiment name } & Monolayer & Horizontal resolution & Simulation type \\
\hline Set 1 & MAM4L1 & 1 & $1^{\circ}$ & Free-running \\
& MAM4L2 & 2 & $1^{\circ}$ & Free-running \\
& MAM4L4 & 4 & $1^{\circ}$ & Free-running \\
& MAM4L8 & 8 & $1^{\circ}$ & Free-running \\
& MAM3 & $\mathrm{n} / \mathrm{a}$ & $1^{\circ}$ & Free-running \\
\hline Set 2 & MAM4R2 & 8 & $2^{\circ}$ & SD \\
& MAM4R1 & 8 & $1^{\circ}$ & SD \\
& MAM4R0.5 & 8 & $0.5^{\circ}$ & SD \\
& MAM4R0.25 & 8 & $0.25^{\circ}$ & SD \\
& MAM3R1 & $\mathrm{n} / \mathrm{a}$ & $1^{\circ}$ & SD \\
\hline
\end{tabular}

ern Africa, South America, Indonesia, and Siberia), but a small fraction of $\mathrm{BC}$ and $\mathrm{POM}$ is transported to the $\mathrm{Pa}-$ cific and Atlantic oceans, and to the Arctic. In general the Southern Hemisphere (SH) high latitudes have the lowest $\mathrm{BC}$ and POM burdens. As expected, BC and POM burdens from CAM5-MAM4 simulations are much higher than those with MAM3 far from source regions. The increase in $\mathrm{BC}$ and POM burdens with MAM4 is most evident for the largest number of monolayers. This is more clearly seen in Fig. 3, which shows the relative (percentage) differences of annual mean burdens of BC and POM between MAM4 and MAM3 for the set 1 experiments. Compared to MAM3, the global total burden increase for MAM4L1 is 10 and $16 \%$, respectively, for BC and POM, while it is 128 and $174 \%$ for MAM4L8. The largest increase occurs over the remote oceans and polar regions where the background concentrations are low (see Fig. 2). An increase by up to a factor of 10 can be seen in the Arctic in the MAM4L8 case. In contrast, the increase is less than a factor of 2 (i.e., less than $100 \%$ ) in the regions over the continents where the major sources are. For a larger threshold number of monolayers, carbonaceous aerosols stay longer in the primary carbon mode, indicating a slower ageing. Aerosol particles in the primary carbon mode are subject to relatively inefficient impaction scavenging by precipitating hydrometeors, but are not subject to in-cloud scavenging, which allows more POM and BC to be transported to the remote regions. We note that non-carbonaceous aerosols (i.e., sulfate, SOA, mineral dust and sea salt) are affected very little (i.e., $\sim 1 \%$ difference for dust, and less than $0.5 \%$ difference for other aerosol species, which are about an order of magnitude smaller than their inter-annual variabilities) by the introduction of the primary carbon mode. The number of $\mathrm{CCN}$ at $0.1 \%$ supersaturation, which is important for the cloud formation and climate, changes by $\sim 6 \%$ on the global mean.
Figure 4 shows the latitudinal and longitudinal distributions of annual mean BC and POM column burdens from the set 2 experiments. With an increase in the horizontal resolution from 2 to $0.25^{\circ}$ for CAM5-MAM4 simulations, BC and POM burdens both increase by $10-20 \%$ on the global mean and by about a factor of 2 in the Antarctic. This increase is due to (1) the resolved meso-scale eddies at higher resolutions, which leads to stronger poleward eddy transport of aerosol species, and (2) less frequent wet scavenging resulting from the reduced frequency of collocation between aerosols and clouds at higher resolutions (Ma et al., 2014). Figure 5 shows the percentage differences of annual mean $\mathrm{BC}$ and POM burdens at $1,0.5$, and $0.25^{\circ}$ relative to $2^{\circ}$ for the set 2 experiments with CAM5-MAM4. With the increase in horizontal resolution, clearly more $\mathrm{BC}$ and $\mathrm{POM}$ are transported to the remote regions. The largest increase occurs in the Antarctic by up to a factor of 2. Other strong increases are seen in regions away from major sources, such as the Arctic, western and eastern Pacific, East Asian and North American pollution outflow regions, indicating the enhanced transport out of the source regions at higher resolutions. The resolution sensitivity of BC and POM, as well as other aerosols, can contribute to the resolution sensitivity of aerosol-cloud interactions such as the enhanced but less frequent droplet nucleation due to stronger subgrid vertical velocity, reduced collocation of aerosols and clouds, and higher aerosol concentration (Ma et al., 2015). The regions with the smallest relative increases are the POM / BC source regions (e.g., East Asia, southern Africa, South America), and the subtropical dry zones where cloud and precipitation scavenging of aerosols is relatively weak.

By comparing MAM4L8 (in Fig. 2) with MAM4R1 (in Fig. 4), all else being the same, CAM5 with the 1-year specific dynamics gives $\sim 20 \%$ lower BC and POM global burdens than the 10-year free-running simulation. This can be partly attributed to the inter-annual variability of aerosols in 


\section{Column burden}

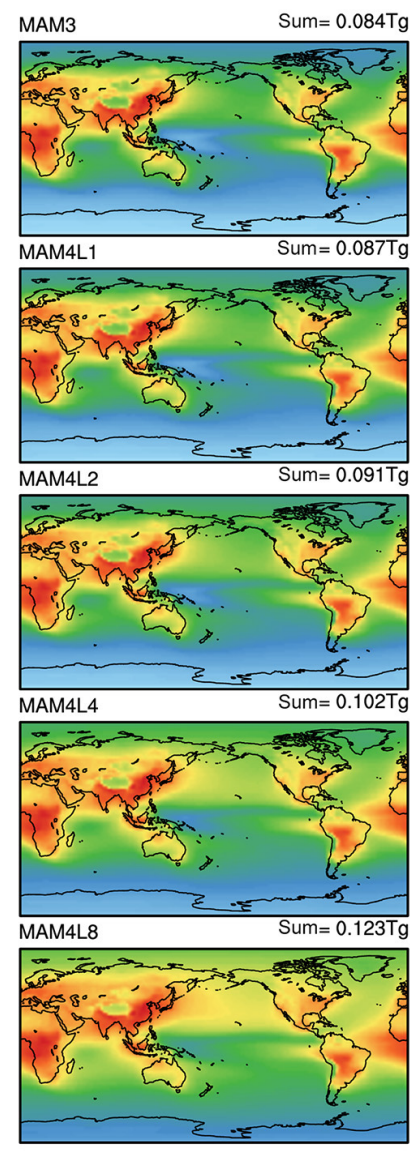

$\begin{array}{lllll}0.01 & 0.1 & 1 & 10 & 100^{\mathrm{BC}}\left(10^{2} \mathrm{ug} / \mathrm{m}^{2}\right)\end{array}$
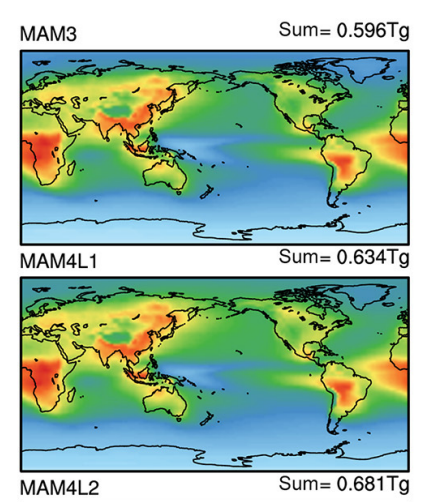

MAM4L2
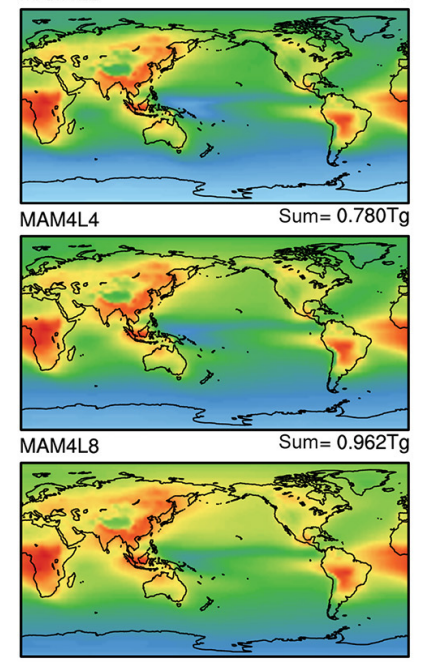

$0.01 \quad 0.1 \quad 1 \quad 10 \quad 100$ POM $\left(10^{3} \mathrm{ug} / \mathrm{m}^{2}\right)$

Figure 2. Latitudinal and longitudinal distributions of annual mean column burdens of BC (in $10^{2} \mu \mathrm{g} \mathrm{m}^{-2}$, left) and POM $\left(10^{3} \mu \mathrm{g} \mathrm{m}^{-2}\right.$, right) from the set 1 experiments with the default MAM3, and MAM4 with different criteria of number of monolayers (i.e., MAM4L1, MAM4L2, MAM4L4, and MAM4L8).

the MAM4L8 simulation. However, the primary cause of this difference is the different meteorological conditions between the SD and the free-running CAM5 that affect the transport and cloud processing of aerosols.

\subsection{Annual global budgets of $\mathrm{BC}$ and POM}

Tables 2 and 3 give the BC and POM budgets, respectively, for the sensitivity to the number of monolayers in the set 1 experiments. Most BC is removed from the atmosphere by wet deposition $(\sim 80 \%)$. When the number of monolayers required for microphysical ageing of $\mathrm{BC}$ from the primary carbon mode to the accumulation mode is increased, the contribution of wet deposition to the total BC sink decreases somewhat and the contribution of dry deposition increases. Most $\mathrm{BC}$ resides in the accumulation mode, indicating the relatively fast ageing of $\mathrm{BC}$ after it is emitted into the primary carbon mode. The ageing timescale of primary carbon

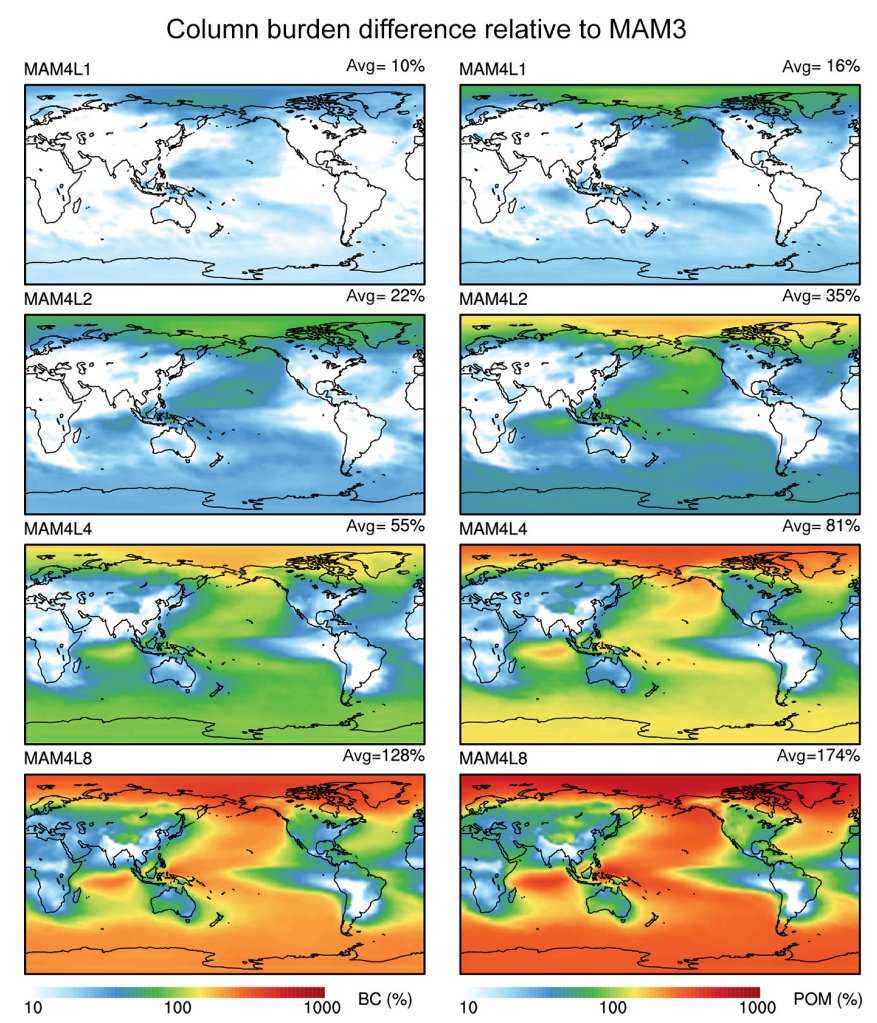

Figure 3. Latitudinal and longitudinal distributions of the relative (percentage) differences of annual mean burdens of BC (left) and POM (right) between MAM4 with different criteria of number of monolayers (i.e., MAM4L1, MAM4L2, MAM4L4, and MAM4L8) and MAM 3 in the set 1 experiments.

mode BC (i.e., burden divided by the ageing flux from primary carbon mode to the accumulation mode) ranges from 0.24 days in MAM4L1 to 2.08 days in MAM4L8. With more monolayers and slower ageing of primary carbonaceous aerosols, more emitted $\mathrm{BC}$ remains in the primary carbon mode, and is not subject to cloud processing. For example, about $30 \%$ of the total BC burden is in the primary carbon mode for the MAM4L8 experiment, compared to $6 \%$ for the MAM4L1 experiment. The total BC burden increases from 0.087 (MAM4L1) to $0.123 \mathrm{Tg}$ (MAM4L8), because the BC lifetime increases from 4.10 (MAM4L1) to 5.79 days (MAM4L8). Interestingly, BC burden in the accumulation mode does not change much in these simulations, because the accumulation mode BC source (from ageing) and lifetime do not change much as the ageing criterion (monolayers) changes (Liu et al., 2012).

Similar results can be derived for POM (Table 3), except that $\mathrm{POM}$ emissions are $\sim 6$ times higher, and the burdens are 7-8 times higher than those of $\mathrm{BC}$ in these simulations. The longer lifetime of POM than that of $\mathrm{BC}$ reflects different spatial and temporal distributions of POM versus BC emissions from different sources (e.g., fossil fuel and biomass burning) with respect to cloud and precipitation distributions. A higher 
Table 2. Global BC budgets for monolayer sensitivity simulations in set 1 experiments. Numbers in parentheses are standard deviations about the 10-year mean representing inter-annual variability.

\begin{tabular}{lrrrrr}
\hline & MAM3 & MAM4L1 & MAM4L2 & MAM4L4 & MAM4L8 \\
\hline Sources $\left(\mathrm{Tg} \mathrm{yr}^{-1}\right)$ & 7.76 & 7.76 & 7.76 & 7.76 & 7.76 \\
$\quad$ Emission & 7.76 & 7.76 & 7.76 & 7.76 & 7.76 \\
Sinks (Tg yr $\left.{ }^{-1}\right)$ & $7.75(0.008)$ & $7.75(0.004)$ & $7.75(0.007)$ & $7.75(0.006)$ & $7.74(0.006)$ \\
Dry deposition & $1.30(0.014)$ & $1.38(0.006)$ & $1.42(0.013)$ & $1.50(0.009)$ & $1.64(0.009)$ \\
Wet deposition & $6.45(0.014)$ & $6.37(0.008)$ & $6.33(0.015)$ & $6.25(0.011)$ & $6.10(0.006)$ \\
Lifetime (days) & $3.95(0.048)$ & $4.10(0.036)$ & $4.30(0.037)$ & $4.80(0.031)$ & $5.79(0.051)$ \\
Burden (Tg) & $0.084(0.001)$ & $0.087(0.008)$ & $0.091(0.0007)$ & $0.102(0.0007)$ & $0.123(0.001)$ \\
in accumulation & $0.084(0.001)$ & $0.082(0.007)$ & $0.082(0.0008)$ & $0.083(0.0007)$ & $0.083(0.001)$ \\
in primary carbon & 0.000 & $0.005(0.0001)$ & $0.009(0.0003)$ & $0.019(0.0005)$ & $0.040(0.0004)$ \\
Ageing timescale of primary carbon (days) & $\mathrm{n} / \mathrm{a}$ & $0.24(0.005)$ & $0.44(0.015)$ & $0.96(0.025)$ & $2.08(0.02)$ \\
\hline
\end{tabular}

Table 3. Same as Table 2, except for POM budgets.

\begin{tabular}{lrrrrr}
\hline & MAM3 & MAM4L1 & MAM4L2 & MAM4L4 & MAM4L8 \\
\hline Sources $\left(\mathrm{Tg} \mathrm{yr}^{-1}\right)$ & 50.2 & 50.2 & 50.2 & 50.2 & 50.2 \\
$\quad$ Emission & 50.2 & 50.2 & 50.2 & 50.2 & 50.2 \\
Sinks $\left(\mathrm{Tg} \mathrm{yr}^{-1}\right)$ & $50.1(0.064)$ & $50.1(0.041)$ & $50.1(0.053)$ & $50.1(0.037)$ & $50.1(0.044)$ \\
$\quad$ Dry deposition & $7.5(0.086)$ & $8.1(0.051)$ & $8.4(0.061)$ & $9.0(0.051)$ & $10.0(0.049)$ \\
$\quad$ Wet deposition & $42.6(0.089)$ & $42.0(0.071)$ & $41.7(0.063)$ & $41.1(0.078)$ & $40.1(0.051)$ \\
Lifetime (days) & $4.34(0.049)$ & $4.62(0.045)$ & $4.96(0.038)$ & $5.69(0.042)$ & $7.02(0.095)$ \\
Burden (Tg) & $0.60(0.007)$ & $0.63(0.006)$ & $0.68(0.005)$ & $0.78(0.006)$ & $0.96(0.013)$ \\
$\quad$ in accumulation & $0.60(0.007)$ & $0.59(0.006)$ & $0.58(0.005)$ & $0.59(0.004)$ & $0.59(0.009)$ \\
$\quad$ in primary carbon & 0.00 & $0.049(0.001)$ & $0.097(0.001)$ & $0.19(0.004)$ & $0.37(0.007)$ \\
Ageing timescale of primary carbon (days) & $\mathrm{n} / \mathrm{a}$ & $0.37(0.008)$ & $0.74(0.008)$ & $1.48(0.03)$ & $2.97(0.06)$ \\
\hline
\end{tabular}

percentage of POM is emitted from biomass burning emissions than for $\mathrm{BC}$, and the biomass burning emissions tend to occur more in tropical dry seasons and boreal non-winter seasons. Also, it is assumed that POM / BC from biomass burning emissions is injected into higher altitudes (up to 6 $\mathrm{km}$ ) and thus is less subject to wet removal by clouds, compared to the POM / BC from fossil fuel, which is emitted near the surface. The inter-annual variation of modeled $\mathrm{BC}$ and POM due to natural variability (i.e., BC and POM difference among different years of 10-year climatology) is quantified to be very small, as indicated by the standard deviations of BC and POM budget terms about the 10-year mean in Tables 2 and 3 for the set 1 experiments.

Tables 4 and 5 give the BC and POM budgets, respectively, for the set 2 experiments. BC and POM burdens increase by 12 and $7 \%$, respectively, from 2 to $0.25^{\circ}$, with the increase occurring in the accumulation mode. The nearly invariant $\mathrm{POM}$ and $\mathrm{BC}$ burdens in the primary carbon mode with resolution indicate that the microphysical ageing of primary carbonaceous aerosols is insensitive to the resolution. This is verified by the nearly constant ageing timescales of primary carbon mode POM and BC. The accumulation mode burden increases are due to longer lifetimes for the accumulation mode aerosol (e.g., 3.38 days versus 3.95 days for BC at $2^{\circ}$ versus $0.25^{\circ}$ resolution). This is due to slower wet removal rates (i.e., wet deposition sinks divided by burdens) at higher resolution, even though the absolute wet removal sinks are slightly greater at higher resolution, and the dry deposition sinks are correspondingly slightly lower. Specified dynamics (MAM4R1) reduces BC and POM burdens by 18 and $14 \%$, respectively, compared to free running (MAM4L8), with most of the decrease occurring in the accumulation mode.

\subsection{Comparison with in situ observations}

Next, we compare the simulations with a data set obtained during the HIAPER (High-Performance Instrumented Airborne Platform for Environmental Research) Pole-toPole Observations (HIPPO) campaigns (HIPPO 1-5) over the remote Pacific from $80^{\circ} \mathrm{N}$ to $67^{\circ} \mathrm{S}$ in January and November 2009, March/April 2010, and June/July and August/September 2011 (Wofsy et al., 2011). Tilmes et al. (2015) evaluated CAM5 with MAM3 against these campaigns, so in this study we focus on evaluating MAM4 results. Figure 6 shows the latitude-altitude cross section of the Single Particle Soot Photometer (SP2) measured BC concentrations during the HIPPO 1-5 campaigns (Schwarz et al., 2013), in comparison with CAM5-MAM4 simulated BC 
Table 4. Global BC budgets for resolution sensitivity simulations in set 2 experiments.

\begin{tabular}{|c|c|c|c|c|c|}
\hline & MAM3R1 & MAM4R2 & MAM4R1 & MAM4R0.5 & MAM4R0.25 \\
\hline Sources $\left(\operatorname{Tg~yr}^{-1}\right)$ & 7.76 & 7.76 & 7.76 & 7.76 & 7.76 \\
\hline Emission & 7.76 & 7.76 & 7.76 & 7.76 & 7.76 \\
\hline Sinks $\left(\operatorname{Tg~yr}^{-1}\right)$ & 7.75 & 7.75 & 7.75 & 7.75 & 7.74 \\
\hline Dry deposition & 1.57 & 2.10 & 2.01 & 1.90 & 1.77 \\
\hline Wet deposition & 6.18 & 5.65 & 5.74 & 5.85 & 5.97 \\
\hline Lifetime (days) & 3.25 & 4.61 & 4.77 & 5.02 & 5.18 \\
\hline Burden (Tg) & 0.069 & 0.098 & 0.101 & 0.107 & 0.110 \\
\hline in accumulation & 0.069 & 0.064 & 0.068 & 0.071 & 0.076 \\
\hline in primary carbon & 0.000 & 0.034 & 0.033 & 0.036 & 0.034 \\
\hline Ageing timescale of primary carbon (days) & $\mathrm{n} / \mathrm{a}$ & 1.80 & 1.73 & 1.88 & 1.77 \\
\hline
\end{tabular}

Table 5. Same as Table 4, except for POM budgets.

\begin{tabular}{|c|c|c|c|c|c|}
\hline & MAM3R1 & MAM4R2 & MAM4R1 & MAM4R0.5 & MAM4R0.25 \\
\hline Sources $\left(\mathrm{Tg} \mathrm{yr}^{-1}\right)$ & 50.2 & 50.2 & 50.2 & 50.2 & 50.2 \\
\hline Emission & 50.2 & 50.2 & 50.2 & 50.2 & 50.2 \\
\hline Sinks $\left(\mathrm{Tg} \mathrm{yr}^{-1}\right)$ & 50.1 & 50.1 & 50.2 & 50.1 & 50.1 \\
\hline Dry deposition & 8.5 & 12.0 & 11.5 & 11.1 & 10.4 \\
\hline Wet deposition & 41.6 & 38.1 & 38.6 & 39.1 & 39.7 \\
\hline Lifetime (days) & 3.64 & 5.91 & 6.03 & 6.27 & 6.35 \\
\hline Burden (Tg) & 0.50 & 0.81 & 0.83 & 0.86 & 0.87 \\
\hline in accumulation & 0.50 & 0.48 & 0.50 & 0.52 & 0.55 \\
\hline in primary carbon & 0.00 & 0.33 & 0.33 & 0.34 & 0.32 \\
\hline Ageing timescale of primary carbon (days) & $\mathrm{n} / \mathrm{a}$ & 2.68 & 2.66 & 2.73 & 2.56 \\
\hline
\end{tabular}

concentrations for the same time periods in the set 2 experiments. Here we only show model simulations from the set 2 experiments where meteorological fields from the YOTC analysis are used to drive the model simulations. Note that the aerosol emissions used in this study are the present-day emissions (i.e., from the year 2000), so the inter-annual variability of emissions (especially for biomass burning emissions) is not accounted for. The highest observed BC concentrations were in March/April 2010 in the NH mid-latitudes, resulting from strong transport of $\mathrm{BC}$ from the East Asian continents to the Pacific (Gao et al., 2014). Observed BC concentrations in the NH were lowest in August/September compared to other seasons, consistent with the strong wet scavenging of aerosols by the East Asian monsoon precipitation in the summer. Elevated BC concentrations in the $\mathrm{NH}$ high latitudes (e.g., Arctic) can be seen throughout the seasons, most evident in the spring time (March/April), with the maximum BC concentrations at 3-7 km, due to the transport from the NH mid-latitudes (Liu et al., 2011; Wang et al., 2013; Ma et al., 2013; Bian et al., 2014). BC concentrations in the $\mathrm{SH}$ over $\sim 50^{\circ} \mathrm{S}$ had a maximum in August/September 2011, and were produced from South American and Australian biomass burning activities in the dry season. The poleward transport of BC in $\mathrm{SH}$ can also be seen at high altitudes over $5 \mathrm{~km}$, particularly during August/September.
CAM5-MAM4 running at the four model resolutions is able to capture the maximum of $\mathrm{BC}$ concentrations in the NH mid-latitudes in March/April 2010. MAM4 shows a better agreement with the HIPPO measurements compared with MAM3 (Tilmes et al., 2015); however, the magnitude is still too low. This could be attributed to the underestimation of BC emissions in East Asia in the IPCC AR5 emission inventory used in CAM5 (Lamarque et al., 2010), as reported by previous studies (e.g., Cohen and Wang, 2014). We also find that the simulated aerosol layers are at higher altitudes than the observations. The maximum of BC concentrations in MAM4 is generally between 5 and $10 \mathrm{~km}$, suggesting that the model still has deficiency in the treatment of convective transport and scavenging of aerosols in CAM5 (Wang et al., 2013). Excessive BC aloft was also found in the HadGEM3UKCA model and was attributed to the coupling of convective transport and convective scavenging (Kipling et al., 2013). This bias is also evident in model simulations in June/July and August/September 2011. Overall, the model overestimates $\mathrm{BC}$ concentrations in the upper troposphere. With the increase in model resolution, more $\mathrm{BC}$ is transported to the polar regions, but increases occur primarily in the upper troposphere and lower stratosphere, and are particularly noticeable in January 2009. 


\section{Column burden}
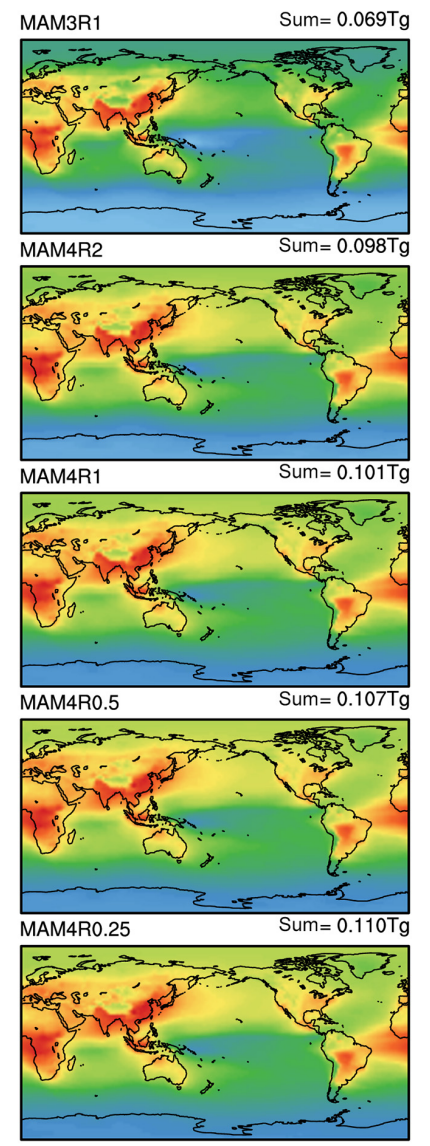

$0.01 \quad 0.1 \quad 1 \quad 10 \quad 100 \mathrm{BC}\left(10^{2} \mathrm{ug} / \mathrm{m}^{2}\right)$
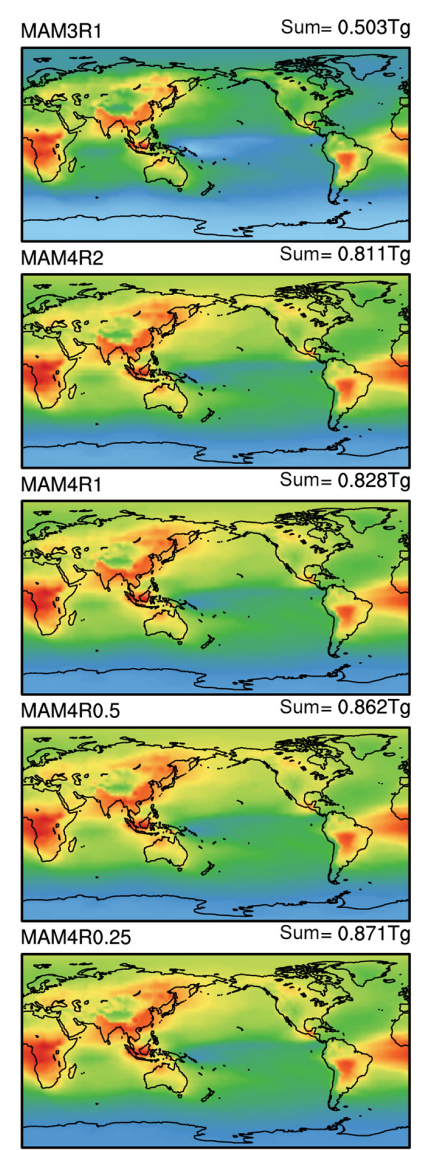

$0.01 \quad 0.1 \quad 1 \quad 10 \quad 100$ POM $\left(10^{3} \mathrm{ug} / \mathrm{m}^{2}\right)$

Figure 4. Latitudinal and longitudinal distributions of annual mean column burdens of BC (in $10^{2} \mu \mathrm{g} \mathrm{m}^{-2}$, left) and POM $\left(10^{3} \mu \mathrm{g} \mathrm{m}^{-2}\right.$, right) from the set 2 experiments with the default MAM3 at $1^{\circ}$ horizontal resolution (MAM3R1), and MAM4 at different horizontal resolutions (i.e., MAM4R2, MAM4R1, MAM4R0.5, and MAM4R0.25).

Figures 7 and 8 compare the modeled BC profiles from the various CAM5 simulations in set 1 and 2 experiments, respectively, with SP2 measured BC profiles during the HIPPO1 campaign over the Arctic and remote Pacific in January 2009 (Schwarz et al., 2010). It is worth noting that the 10 -year average from our set 1 experiments is viewed as an ensemble mean from 10 realizations, representing the freerunning model's present-day $\mathrm{BC}$ climatology, while the observations represent BC in specific years (which depend on the specific observations). In contrast, our set 2 experiments are nudged toward the year 2009 meteorology. The differences in BC from MAM4L8 of set 1 and MAM4R1 of set 2 are due to differences in their meteorology (winds, clouds, and precipitation), which include the differences between a 10-year average (or ensemble) and a single year, as well as the differences between the free-running model's mete-

Column burden difference relative to MAM4R2

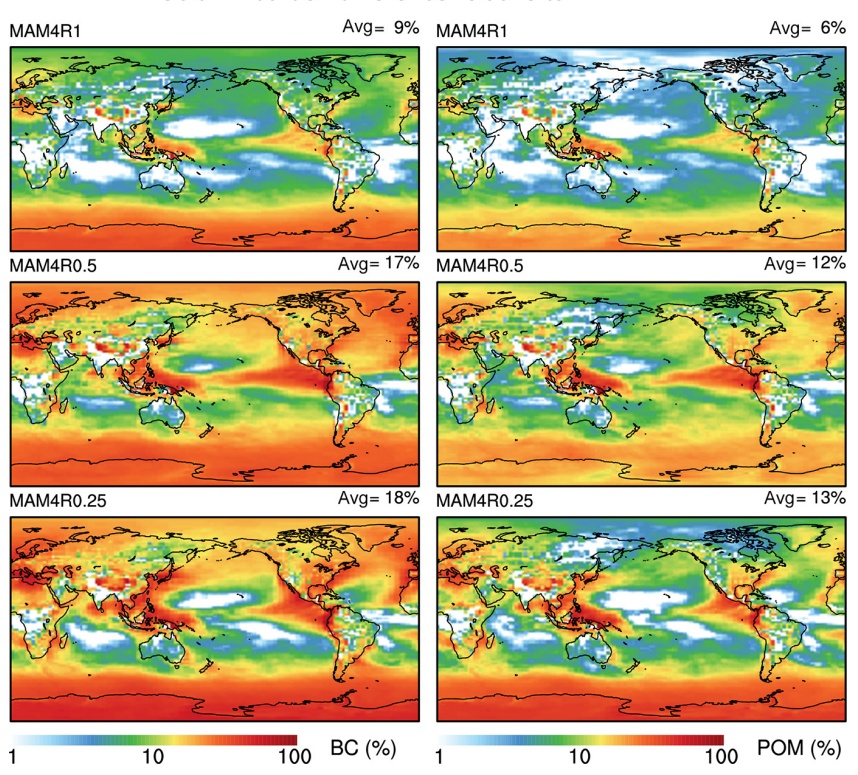

Figure 5. Latitudinal and longitudinal distributions of the relative (percentage) differences of annual mean burdens of BC (left) and POM (right) from the set 2 experiments with MAM4 at 1, 0.5, and $0.25^{\circ}$ relative to $2^{\circ}$ horizontal resolution.

orology and the nudged model's meteorology (which is very close to the reanalysis).

As seen in Fig. 7, vertical profiles of observed mean BC concentrations show strong variability with latitude zones, and standard deviations of observed $\mathrm{BC}$ concentrations are also large. The observations show that $\mathrm{BC}$ concentrations increase with altitude in the SH high latitudes $\left(60-67^{\circ} \mathrm{S}\right)$, indicating the poleward transport of $\mathrm{BC}$ in the upper troposphere by the general circulation. At mid-latitudes $\left(20-60^{\circ} \mathrm{N}\right.$ and $20-60^{\circ} \mathrm{S}$ ), less vertical variation is observed. In the tropics $\left(20^{\circ} \mathrm{S}-20^{\circ} \mathrm{N}\right), \mathrm{BC}$ concentrations increase with altitude and reach a maximum near $700 \mathrm{hPa}$, likely from biomass burning, and then reduce rapidly with height. Over the NH high latitudes $\left(60-80^{\circ} \mathrm{N}\right)$, a steady decreasing trend with height is found. All the model simulations are able to capture vertical distributions of $\mathrm{BC}$ in the $\mathrm{SH}$ high latitudes as well as $\mathrm{SH}$ and $\mathrm{NH}$ mid-latitudes, although the MAM4 simulations with a larger number of monolayers (e.g., MAM4L8) show too high $\mathrm{BC}$ concentrations in the SH high latitudes. The model simulations overestimate $\mathrm{BC}$ concentrations in the upper troposphere in all the latitude zones, while they significantly underestimate observed $\mathrm{BC}$ concentrations at lower altitudes (below $400 \mathrm{hPa}$ ) in the $\mathrm{NH}$ high latitudes. The low bias of $\mathrm{BC}$ concentrations near the surface in the NH high latitudes is improved with MAM4, but there is still an obvious discrepancy between the model simulations and observations. In addition, MAM4 predicts higher $\mathrm{BC}$ concentrations than those from MAM3 at all altitudes and all latitude zones in the set 1 experiments (Fig. 7). With the increase in the num- 

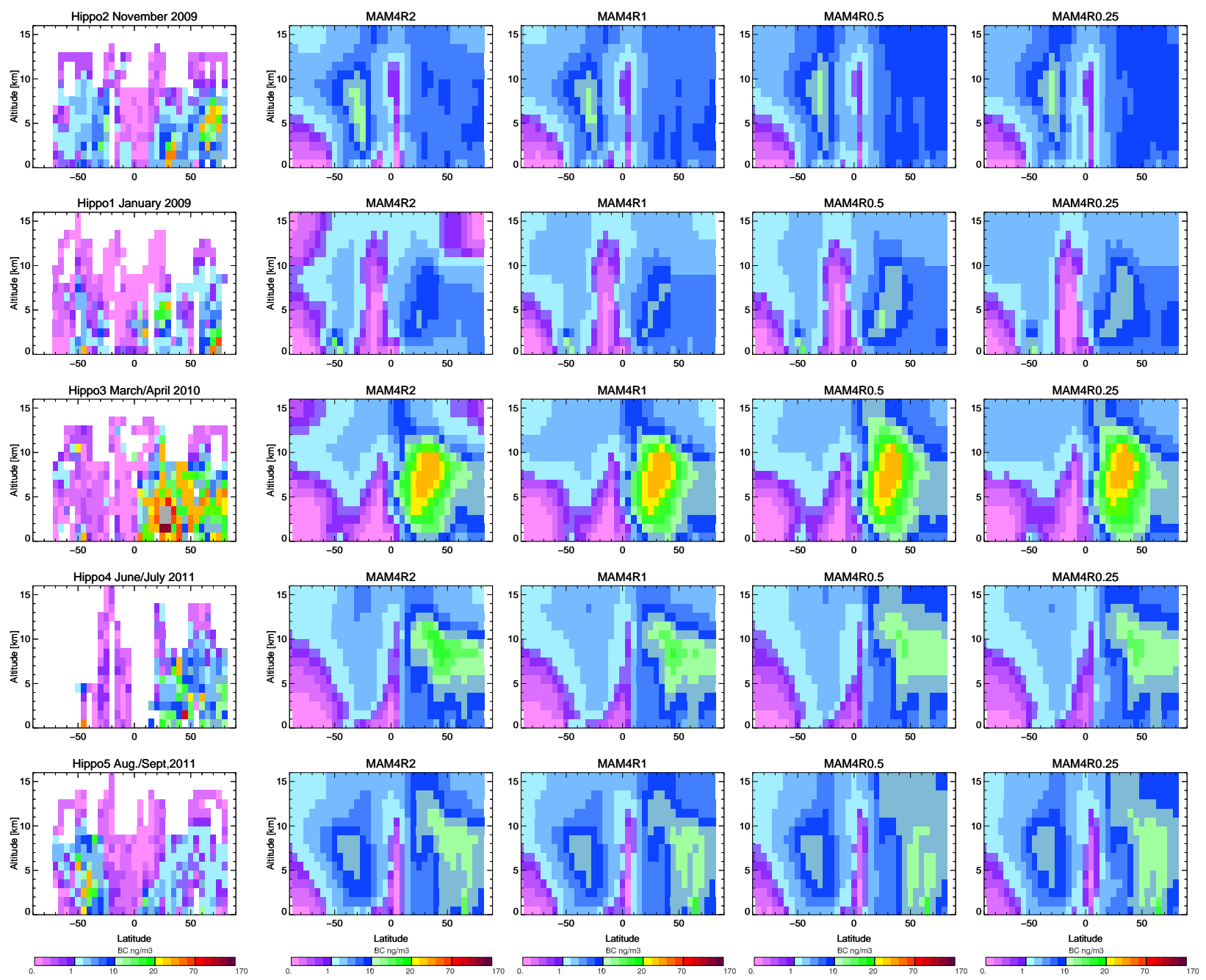

Figure 6. Latitude and altitude cross section of observed and simulated BC concentrations (in ng $\mathrm{m}^{-3}$ ) during the HIAPER (HighPerformance Instrumented Airborne Platform for Environmental Research) Pole-to-Pole Observations (HIPPO) campaigns (HIPPO 1-5) over the remote Pacific from $80^{\circ} \mathrm{N}$ to $67^{\circ} \mathrm{S}$ in January and November 2009, March/April 2010, and June/July and August/September 2011. MAM4 simulated BC concentrations for the same time periods in the set 2 experiments at different horizontal resolutions (i.e., MAM4R2, MAM4R1, MAM4R0.5, and MAM4R0.25) are used for comparison. The model simulations are sampled along the flight paths.

ber of monolayers required for the ageing of primary carbonaceous aerosols in MAM4, modeled BC concentrations increase by up to a factor of 10 . The same is true for the higher BC concentrations with MAM4 than MAM3 for the set 2 experiments at most altitudes (Fig. 8). However, modeled $\mathrm{BC}$ concentrations from MAM3 at $1^{\circ}$ are higher than those from MAM4 at $2^{\circ}$ in the upper troposphere and lower stratosphere. Modeled BC concentrations increase substantially at these altitudes from 2 to $1^{\circ}$. However, the changes are much smaller from 1 to $0.25^{\circ}$ at all altitudes for all latitude zones.

Figures 9 and 10 compare observed $\mathrm{BC}$ vertical profiles from four aircraft campaigns in the tropics (CR-AVE and TC4), NH subtropics (AVE-Houston) and NH mid-latitudes (CARB) with simulations from the set 1 and set 2 experi- ments, respectively. AVE-Houston, CR-AVE, and TC4 are documented in Schwarz et al. (2006) and CARB is documented in Clarke et al. (2007), Howell et al. (2006), and McNaughton et al. (2009). Observed BC mean concentrations show a strong reduction from the boundary layer to the free troposphere in the tropics (CR-AVE and TC4) and in the subtropics (AVE-Houston), while there is less vertical variation of $\mathrm{BC}$ concentrations in the upper troposphere. For the AVE-Houston, CR-AVE, and TC4 campaigns, the model experiments with different numbers of monolayers required for ageing of primary carbonaceous aerosols overestimate $\mathrm{BC}$ concentrations in the middle and upper troposphere (Fig. 9), but compare better with observations in the lower troposphere. The CARB campaign in the mid-latitudes of North America in June encountered biomass burning plumes, 

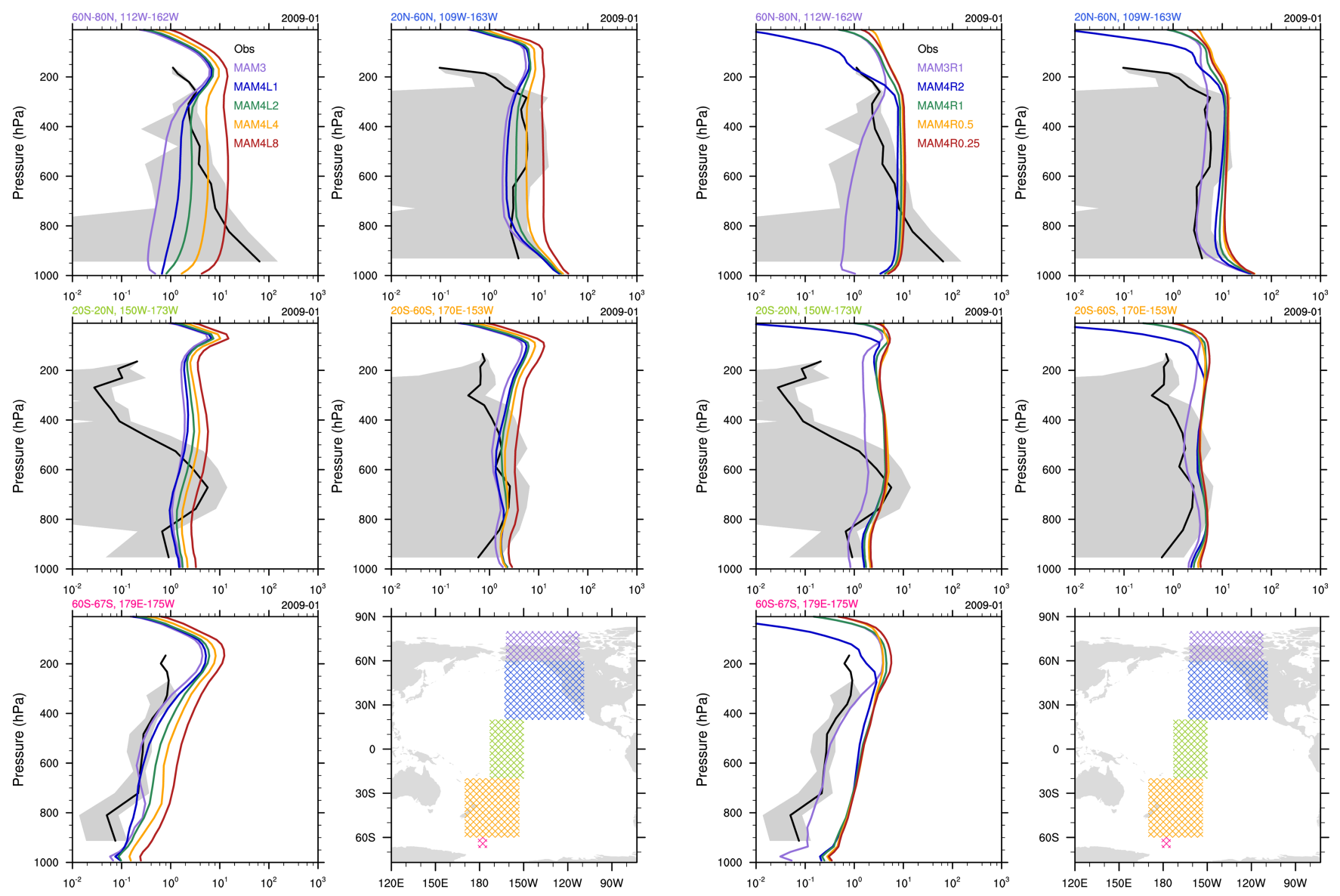

Figure 7. Observed and simulated vertical profiles of BC concentrations (in $\mathrm{ng} \mathrm{kg}^{-1}$ ) during the HIPPO1 campaign over the Arctic and remote Pacific in January 2009. Dark solid curves are for observation means, and shaded areas for the plus/minus 1 standard deviation of observations. The CAM5 simulations in the set 1 experiments (i.e., MAM3, MAM4L1, MAM4L2, MAM4L4, and MAM4L8) are used for comparison. Simulated profiles are averaged over the points on the map and the indicated month of the field campaign.

and elevated $\mathrm{BC}$ concentrations were observed at $\sim 800 \mathrm{hPa}$, which are not captured by model simulations using the AR5 emission inventory. The SD simulations at higher resolutions in the set 2 experiments (Fig. 10) do not improve the overall agreement with observations, which indicates the necessity of improving the model physics (e.g., aerosol processing in convective clouds) and aerosol emissions (e.g., for biomass burning aerosols). The modeled $\mathrm{BC}$ concentrations do not change significantly with different model resolutions, although there is an increasing trend with increasing the resolution.

Figures 11 and 12 compare observed $\mathrm{BC}$ vertical profiles from two aircraft campaigns in the $\mathrm{NH}$ high latitudes, ARCTAS (Jacob et al., 2010) and ARCPAC (Brock et al., 2011), with the set 1 and set 2 experiments, respectively. Ob-
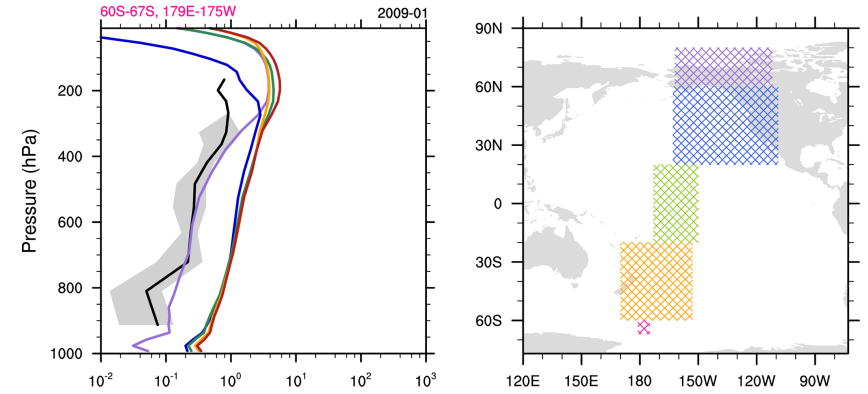

Figure 8. Same as Fig. 7, except for CAM5 simulations in the set 2 experiments (i.e., MAM3R1, MAM4R2, MAM4R1, MAM4R0.5, and MAM4R0.25).

served $\mathrm{BC}$ concentrations show less vertical variations from the surface to $\sim 300 \mathrm{hPa}$ than those in the tropics and $\mathrm{NH}$ mid-latitudes, especially in the spring. This results from the poleward transport of $\mathrm{BC}$ from NH mid-latitudes at high altitudes. Model simulations in the set 1 experiments underestimate observed BC concentrations below altitudes of $\sim 300$ $400 \mathrm{hPa}$ by $1-2$ orders of magnitude, especially in spring (Fig. 11). Introducing the primary carbon mode with the number of monolayers increasing from 1 to 8 substantially increases the modeled $\mathrm{BC}$ concentrations in the spring, in much better agreement with observations. However, the improvement of $\mathrm{BC}$ simulation in the summer is less substantial. The difference of BC concentrations between MAM3 and MAM4 and among different MAM4 experiments is much smaller in the summer, similar in magnitude to the changes in the tropics and $\mathrm{NH}$ mid-latitudes (Fig. 9). Model simulations in the set 2 experiments show the increase in BC concentrations with MAM4, compared to MAM3, but the increase in model resolution does not produce a significant increase in BC concentrations at altitudes below $\sim 200 \mathrm{hPa}$ (Fig. 12). 

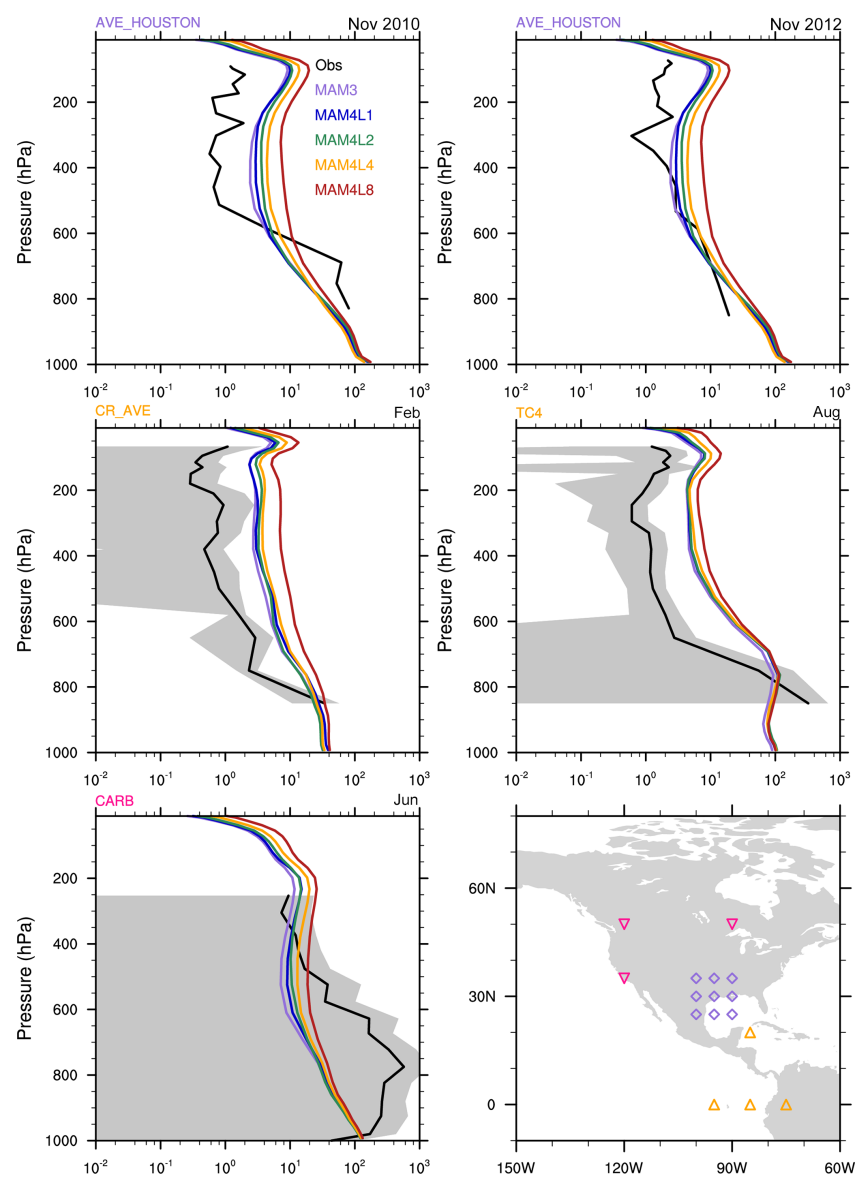

Figure 9. Observed and simulated vertical profiles of BC concentrations (in $\mathrm{ng} \mathrm{kg}^{-1}$ ) from four aircraft campaigns in the tropics, NH subtropics and NH mid-latitudes: AVE-Houston (NASA Houston Aura Validation Experiment) in November 2010 and 2012, respectively, CR-AVE (NASA Costa Rica Aura Validation Experiment) in February 2006, TC4 (Tropical Composition, Cloud and Climate Coupling) in August 2007, and CARB (NASA initiative in collaboration with California Air Resources Board) in June 2008. Observations are averages for the respective campaigns with dark solid curves for observation means, and shaded areas for the plus/minus 1 standard deviation of observations. Simulated profiles for the CAM5 simulations in the set 1 experiments (i.e., MAM3, MAM4L1, MAM4L2, MAM4L4, and MAM4L8) are averaged over the points on the map and the indicated month of the respective field campaign.

Figures 13 and 14 show the seasonal variations of observed BC surface concentrations at four polar sites, in comparison with the model results from MAM4 set 1 and 2 experiments, respectively, along with the results from MAM3. Observed BC concentrations at the three Arctic sites show a strong seasonality with higher concentrations in boreal spring and winter, and much lower concentrations in boreal summer (by about 1 order of magnitude). Observed BC concentrations at the Antarctic site are lower by 1 order of magnitude than those in the Arctic, and the seasonality is
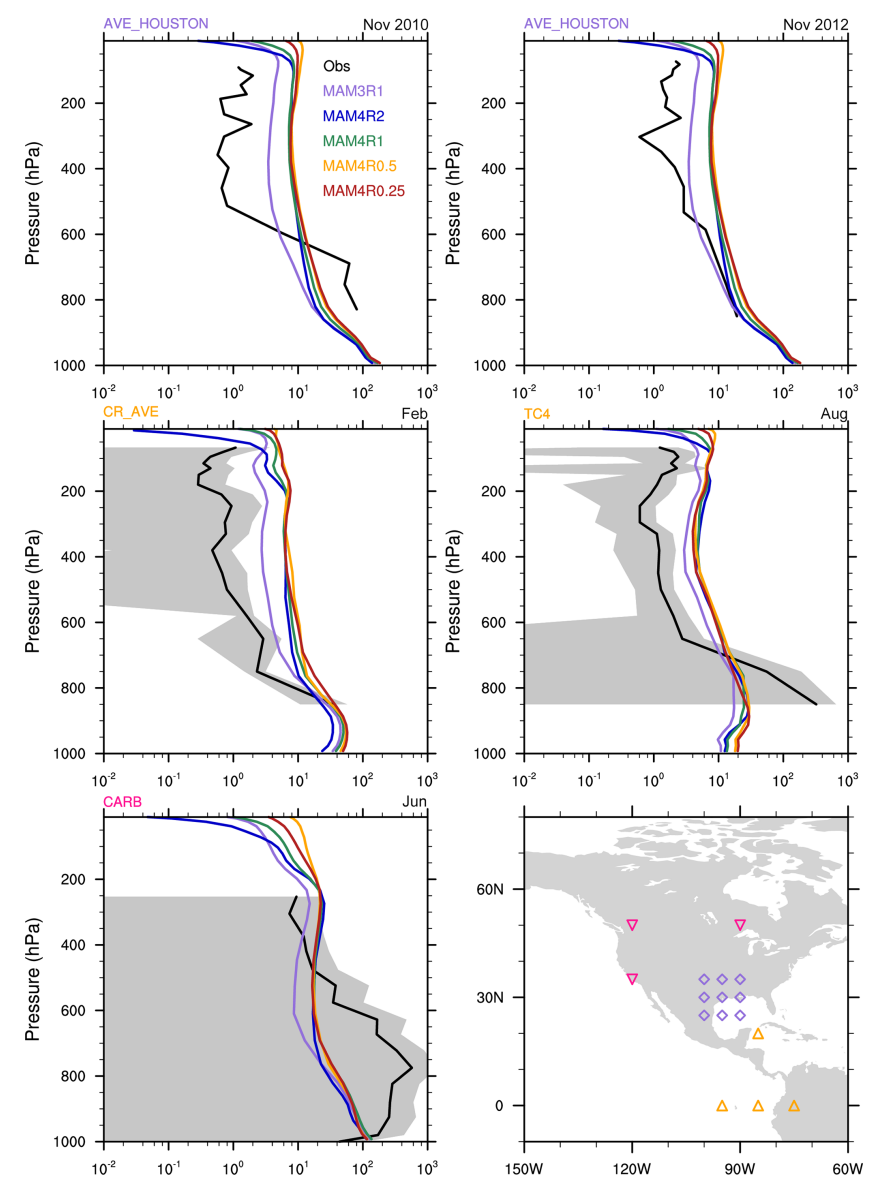

Figure 10. Same as Fig. 9, except for CAM5 simulations in the set 2 experiments (i.e., MAM3R1, MAM4R2, MAM4R1, MAM4R0.5, and MAM4R0.25).

weaker and different, with highest BC concentrations in the austral spring and summer. At the Arctic sites, CAM5 with MAM3 substantially underestimates the observed BC concentrations, especially in winter by more than 2 orders of magnitude, and produces an opposite seasonality to the observed one. This indicates the too efficient wet scavenging of $\mathrm{BC}$ during its transport from the mid-latitudes, especially in spring and winter, since uncertainty of the emissions cannot explain these large discrepancies. CAM5-MAM4, especially with the larger number of monolayers, significantly increases the $\mathrm{BC}$ concentrations at the Arctic sites, especially in winter, and thus improves the modeled seasonality of $\mathrm{BC}$ concentrations. Simulated BC concentrations also increase at the Antarctic site, but the seasonality is still wrong. Increasing the model resolution of CAM5-MAM4 results in a general increase in $\mathrm{BC}$ concentrations in different seasons, especially in summer at the Arctic sites, which, however, weakens the simulated seasonality. 

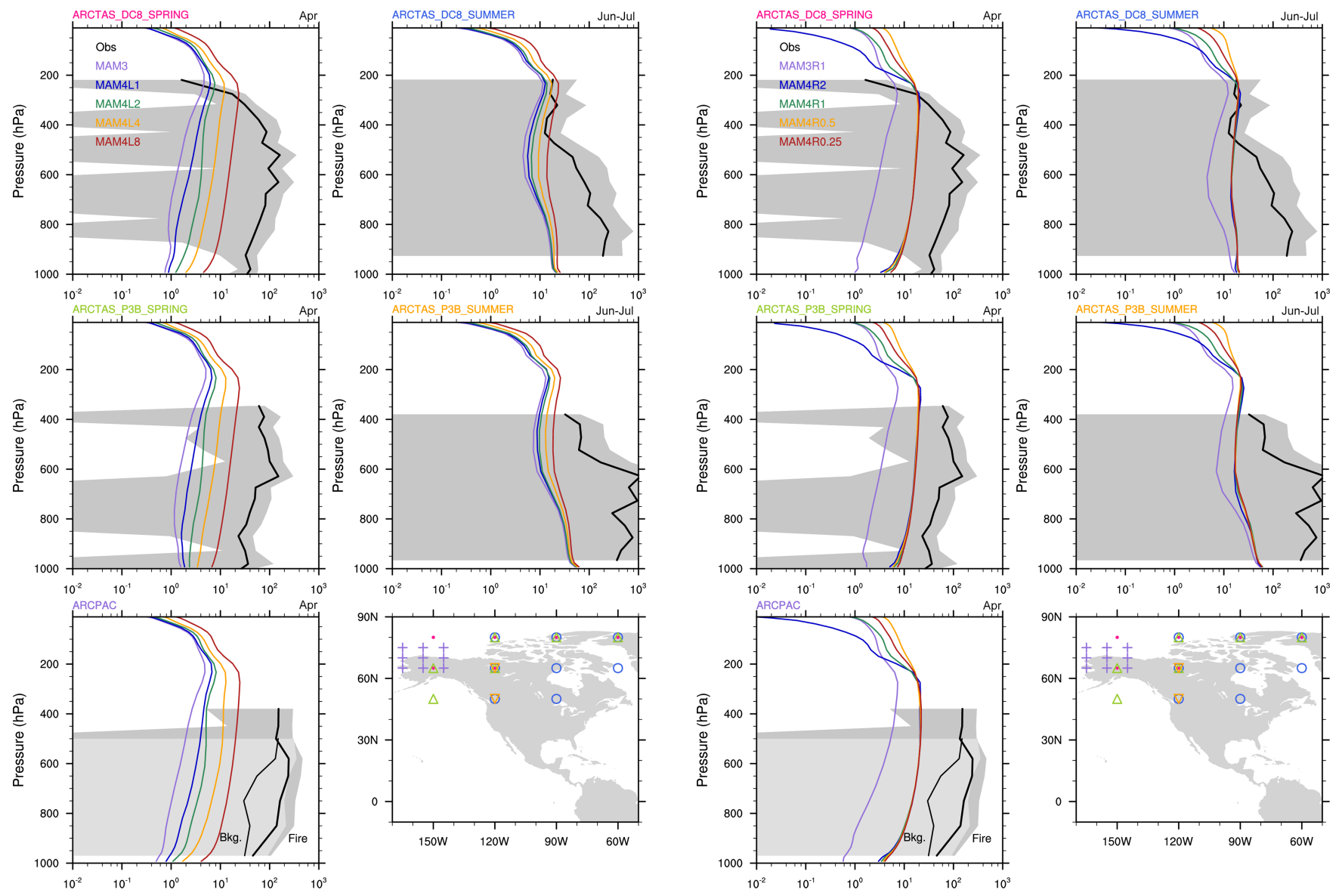

Figure 11. Same as Fig. 9, except for BC profiles in the NH high latitudes from two other aircraft campaigns: ARCTAS (NASA Arctic Research of the Composition of the Troposphere from Aircraft and Satellite) in spring (April) and summer (June-July) 2008, and ARCPAC (NOAA Aerosol, Radiation, and Cloud Processes affecting Arctic Climate) in spring (April) 2008. Simulated profiles are averaged over the points on the map and the indicated month of the respective field campaign.

\section{Discussion and conclusions}

To reduce the biases of carbonaceous aerosol simulated in CAM5, a new four-mode version of MAM (MAM4) has been developed by adding a primary carbon mode to the default three-mode version (MAM3), and by explicitly treating the microphysical ageing of primary carbonaceous aerosols from the primary carbon mode to the accumulation mode. The computational time increases slightly by $10 \%$, comparing to CAM5 with MAM3. As expected, CAM5-MAM4 increases $\mathrm{BC}$ and $\mathrm{POM}$ burdens and enhances $\mathrm{BC}$ transport to remote regions (e.g., Arctic) due to the reduced wet scavenging of $\mathrm{BC}$ with more $\mathrm{BC}$ residing in the primary carbon mode. The increases are stronger with an increasing number of hygroscopic monolayers required for the ageing of primary carbonaceous aerosols. The global burdens of BC and POM in- 

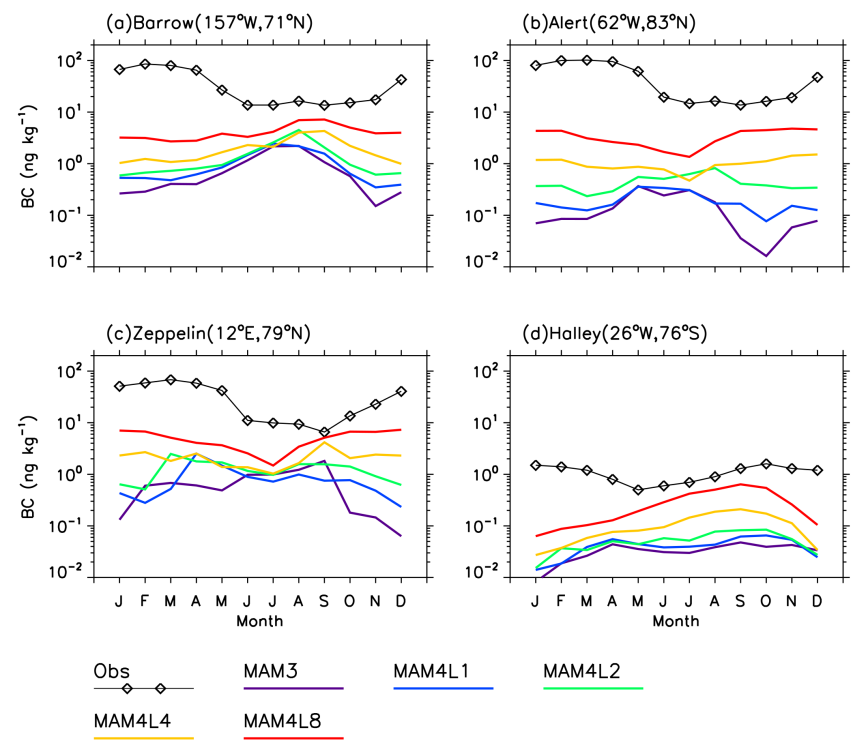

MAM4L2

MAM4L4

Figure 13. Seasonal variations of observed and simulated BC surface concentrations (in $\mathrm{n} \mathrm{kg}^{-1}$ ) at four polar sites. CAM5 simulations in the set 1 experiments (i.e., MAM3, MAM4L1, MAM4L2, MAM4L4, and MAM4L8) are used for comparison.

aerosol plumes from clouds and precipitation (Ma et al., 2014).

Modeled BC was compared to observations obtained from aircraft campaigns and at polar surface sites. For the vertical profiles of BC concentrations, CAM5-MAM4 increases the $\mathrm{BC}$ concentrations at all altitudes compared to MAM3. Therefore, MAM4 improves the modeled BC in the lower troposphere, especially in the Arctic. The modeled nearsurface BC concentrations at the Arctic sites have stronger increases in boreal winter and spring than in summer, which improves the modeled seasonal variation of $\mathrm{BC}$ concentrations. However, modeled near-surface BC concentrations in the polar regions are still lower by 1 order of magnitude compared to observations, even with the number of monolayers of 8 and with the model resolution of $0.25^{\circ}$. This points to the potential problems of emissions and/or other model processes besides the ageing of primary carbonaceous aerosols discussed in this study. Wang et al. (2013) found that the wet scavenging of BC might be too efficient in CAM5 due to too high liquid cloud fractions in the NH high latitudes, based on comparison of CAM5 wet scavenging rates with those from the multi-scale modeling framework (MMF) (Wang et al., 2011). By modifying the treatment of liquid cloud fraction used in the aerosol activation parameterization, Wang et al. (2013) achieved a much better simulation of near-surface $\mathrm{BC}$ and other aerosol species in the Arctic compared to the standard CAM5. In addition, the aerosol emission inventories used in our simulations also likely contribute to the $\mathrm{BC}$ low biases in the Arctic. They neglect gas flaring emissions in and around the Arctic (Stohl et al., 2013), and they may
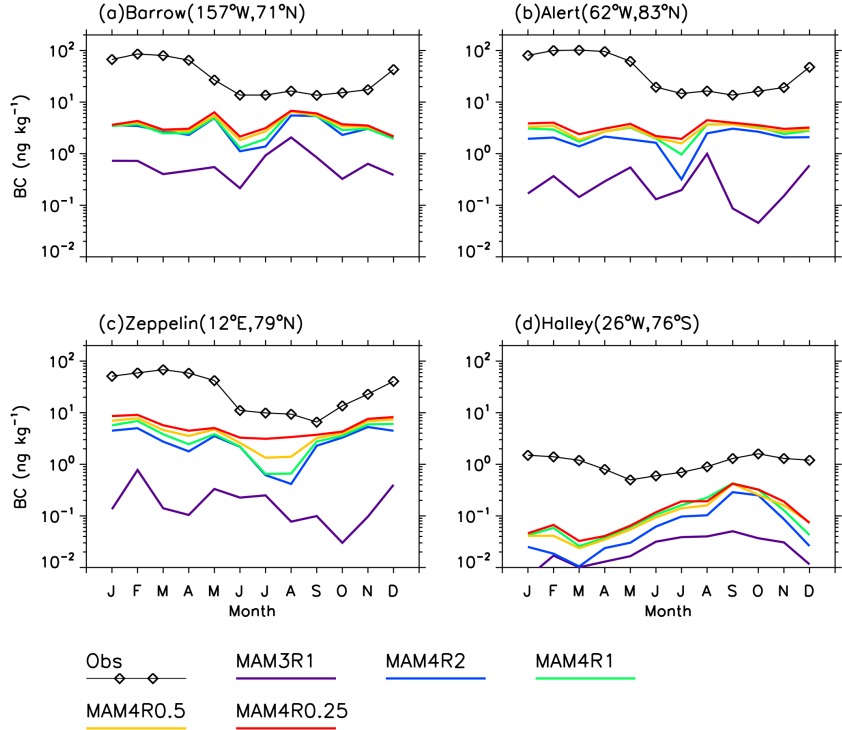

Figure 14. Same as Fig. 13, except for CAM5 simulations in the set 2 experiments (i.e., MAM3R1, MAM4R2, MAM4R1, MAM4R0.5, and MAM4R0.25).

underestimate fossil fuel emissions in East Asia (Cohen and Wang, 2014).

While the modeled $\mathrm{BC}$ low bias in the lower troposphere is significantly reduced in the Arctic, the overestimation of BC concentrations in the middle and upper troposphere over the Pacific and in the tropics and subtropics of North America is exacerbated with MAM4, based on the comparisons with several aircraft campaigns. With a unified treatment of vertical transport and in-cloud wet removal in convective clouds in CAM5, Wang et al. (2013) significantly reduced the biases of aerosol distributions in the remote free troposphere predicted by CAM5, due to the inclusion of secondary activation and thus more efficient scavenging of aerosols in convective clouds. An ongoing joint effort between PNNL and NCAR is underway to merge the MAM4 with this unified treatment of convective transport and scavenging. A more recent improved model treatment in the resuspension of aerosols from evaporated raindrops, releasing aerosol particles to the coarse mode instead of their originating mode upon complete evaporation of raindrops (Easter et al., personal communication, 2015), has shown a significant impact on the vertical distribution of aerosols, including large reductions in middle and upper tropospheric BC and POM. This emphasizes the importance of improving the representations of clouds and precipitation and aerosol-cloud interactions in GCMs.

We note that in this study, we only present the results and analysis of primary carbonaceous aerosols, especially BC, since there have been more BC measurements, and POM is co-emitted with BC. The lifecycle and global budgets of other aerosol species such as sulfate, SOA, sea salt and dust are not presented in this study, since introducing the primary 
carbon mode has a negligible effect on these aerosol species. This is expected since sulfate and SOA primarily reside in the accumulation mode, while dust and sea salt are mostly in the accumulation and coarse modes. Changes in modeled CCN concentrations are also small. The change in the "effective" radiative forcing due to anthropogenic aerosolradiation and anthropogenic aerosol-cloud interactions induced by the MAM4 implementation is less than $0.1 \mathrm{~W} \mathrm{~m}^{-2}$ in the global mean.

\section{Code availability}

The release of CESM version 1.2.0 (with CAM5.3) can be obtained at http://www.cesm.ucar.edu/models/cesm1.2/. Code modifications for the four-mode version of the Modal Aerosol Module are available upon request by contacting the corresponding author.

Acknowledgements. This work was supported by the U.S. Department of Energy, Office of Biological and Environmental Research, Earth System Modeling Program. The Pacific Northwest National Laboratory is operated for DOE by Battelle Memorial Institute under contract DE-AC05-76RL01830. The National Center for Atmospheric Research is funded by the National Science Foundation.

Edited by: G. Mann

\section{References}

Abdul-Razzak, H. and Ghan, S. J.: A parameterization of aerosol activation 2. Multiple aerosol types, J. Geophys. Res., 105, 68376844, 2000

Adachi, K., Chung, S. H., and Buseck, P. R.: Shapes of soot aerosol particles and implications for their effects on climate, J. Geophys. Res., 115, D15206, doi:10.1029/2009JD012868, 2010.

Bauer, S. E., Wright, D. L., Koch, D., Lewis, E. R., McGraw, R., Chang, L.-S., Schwartz, S. E., and Ruedy, R.: MATRIX (Multiconfiguration Aerosol TRacker of mIXing state): an aerosol microphysical module for global atmospheric models, Atmos. Chem. Phys., 8, 6003-6035, doi:10.5194/acp-8-60032008, 2008.

Bian, H., Colarco, P. R., Chin, M., Chen, G., Rodriguez, J. M., Liang, Q., Blake, D., Chu, D. A., da Silva, A., Darmenov, A. S., Diskin, G., Fuelberg, H. E., Huey, G., Kondo, Y., Nielsen, J. E., Pan, X., and Wisthaler, A.: Source attributions of pollution to the Western Arctic during the NASA ARCTAS field campaign, Atmos. Chem. Phys., 13, 4707-4721, doi:10.5194/acp-13-47072013, 2013.

Bond, T. C., Doherty, S. J., Fahey, D. W., Forster, P., Berntsen, T., DeAngelo, B. J., Flanner, M. G., Ghan, S. J., Karcher, B., Koch, D., Kinne, S., Kondo, Y., Quinn, P. K., Sarofim, M., Schultz, M., Schulz, M., Venkataraman, C., Zhang, H., Zhang, S., Bellouin, N., Guttikunda, S. K., Hopke, P. K., Jacobson, M. Z., Kaiser, J. W., Klimont, Z., Lohmann, U., Schwarz, J. P., Shindell, D., Storelvmo, T., Warren, S. G., and Zender,
C. S.: Bounding the role of black carbon in the climate system: A scientific assessment, J. Geophys. Res., 118, 5380-5552, doi:10.1002/jgrd.50171, 2013.

Bretherton, C. S. and Park, S.: A new moist turbulence parameterization in the Community Atmosphere Model, J. Climate, 22, 3422-3448, 2009.

Brock, C. A., Cozic, J., Bahreini, R., Froyd, K. D., Middlebrook, A. M., McComiskey, A., Brioude, J., Cooper, O. R., Stohl, A., Aikin, K. C., de Gouw, J. A., Fahey, D. W., Ferrare, R. A., Gao, R.-S., Gore, W., Holloway, J. S., Hübler, G., Jefferson, A., Lack, D. A., Lance, S., Moore, R. H., Murphy, D. M., Nenes, A., Novelli, P. C., Nowak, J. B., Ogren, J. A., Peischl, J., Pierce, R. B., Pilewskie, P., Quinn, P. K., Ryerson, T. B., Schmidt, K. S., Schwarz, J. P., Sodemann, H., Spackman, J. R., Stark, H., Thomson, D. S., Thornberry, T., Veres, P., Watts, L. A., Warneke, C., and Wollny, A. G.: Characteristics, sources, and transport of aerosols measured in spring 2008 during the aerosol, radiation, and cloud processes affecting Arctic Climate (ARCPAC) Project, Atmos. Chem. Phys., 11, 2423-2453, doi:10.5194/acp-11-24232011, 2011.

Clarke, A. D., McNaughton, C., Kapustin, V., Shinozuka, Y., Howell, S., Dibb, J., Zhou, J., Anderson, B., Brekhovskikh, V., Turner, H., and Pinkerton, M.: Biomass burning and pollution aerosol over North America: Organic components and their influence on spectral optical properties and humidification response, J. Geophys. Res., 112, D12S18, doi:10.1029/2006JD007777, 2007.

Cohen, J. B. and Wang, C.: Estimating global black carbon emissions using a top-down Kalman Filter approach, J. Geophys. Res., 119, 307-323, doi:10.1002/2013JD019912, 2014.

Cooke, W. F. and Wilson, J. J. N.: A global black carbon aerosol model, J. Geophys. Res., 101, 19395-19409, 1996.

Flanner, M. G., Zender, C. S., Randerson, J. T., and Rasch, P. J.: Present-day climate forcing and response from black carbon in snow, J. Geophys. Res., 112, D11202, doi:10.1029/2006JD008003, 2007.

Flanner, M. G., Zender, C. S., Hess, P. G., Mahowald, N. M., Painter, T. H., Ramanathan, V., and Rasch, P. J.: Springtime warming and reduced snow cover from carbonaceous particles, Atmos. Chem. Phys., 9, 2481-2497, doi:10.5194/acp-9-24812009, 2009.

Flanner, M. G., Liu, X., Zhou, C., Penner, J. E., and Jiao, C.: Enhanced solar energy absorption by internally-mixed black carbon in snow grains, Atmos. Chem. Phys., 12, 4699-4721, doi:10.5194/acp-12-4699-2012, 2012.

Forster, P., Ramaswamy, V., Artaxo, P., Berntsen, T., Betts, R., Fahey, D. W., Haywood, J., Lean, J., Lowe, D. C., Myhre, G., Nganga, J., Prinn, R., Raga, G., Schulz, M., and Van Dorland, $\mathrm{R}$ : Changes in atmospheric constituents and in radiative forcing, in: Climate Change 2007: The Physical Science Basis, Contribution of Working Group I to the Fourth Assessment Report of the Intergovernmental Panel on Climate Change, Cambridge University Press, Cambridge, New York, 129-234, 2007.

Gao, Y., Zhao, C., Liu, X., Zhang, M., and Leung, L.-R.: WRFChem simulations of aerosols and anthropogenic aerosol radiative forcing in East Asia, Atmos. Environ., 92, 250-266, doi:10.1016/j.atmosenv.2014.04.038, 2014.

Gettelman, A., Liu, X., Ghan, S. J., Morrison, H., Park, S., Conley, A. J., Klein, S. A., Boyle, J., Mitchell, D. L., and Li, J.-L. F.: Global simulations of ice nucleation and ice su- 
persaturation with an improved cloud scheme in the Community Atmosphere Model. J. Geophys. Res., 115, D18216, doi:10.1029/2009JD013797, 2010.

Ghan, S. J. and Easter, R. C.: Impact of cloud-borne aerosol representation on aerosol direct and indirect effects, Atmos. Chem. Phys., 6, 4163-4174, doi:10.5194/acp-6-4163-2006, 2006.

Hansen, J. and Nazarenko, L.: Soot climate forcing via snow and ice albedos, P. Natl. Acad. Sci. USA, 101, 423-428, 2004.

Hansen, J., Sato, M., Ruedy, R., Nazarenko, L., Lacis, A., Schmidt, G. A., Russell, G., Aleinov, I., Bauer, M., Bauer, S., Bell, N., Cairns, B., Canuto, V., Chandler, M., Cheng, Y., Genio, A. D., Faluvegi, G., Fleming, E., Friend, A., Hall, T., Jackman, C., Kelley, M., Kiang, N., Koch, D., Lean, J., Lerner, J., Lo, K., Menon, S., Miller, R., Minnis, P., Novakov, T., Oinas, V., Perlwitz, J., Perlwitz, J., Rind, D., Romanou, A., Shindell, D., Stone, P., Sun, S., Tausnev, N., Thresher, D., Wielicki, B., Wong, T., Yao, M., and Zhang, S.: Efficacy of climate forcings, J. Geophys. Res., 110, D18104, doi:10.1029/2005JD005776, 2005.

Howell, S. G., Clarke, A. D., Shinozuka, Y., Kapustin, V., McNaughton, C. S., Huebert, B. J., Doherty, S. J., and Anderson, T. L.: Influence of relative humidity upon pollution and dust during ACE-Asia: Size distributions and implications for optical properties, J. Geophys. Res., 111, D06205, doi:10.1029/2004JD005759, 2006.

Iacono, M. J., Delamere, J. S., Mlawer, E. J., Shephard, M. W., Clough, S. A., and Collins, W. D.: Radiative forcing by long-lived greenhouse gases: Calculations with the AER radiative transfer models, J. Geophys. Res., 113, D13103, doi:10.1029/2008jd009944, 2008.

Jacob, D. J., Crawford, J. H., Maring, H., Clarke, A. D., Dibb, J. E., Emmons, L. K., Ferrare, R. A., Hostetler, C. A., Russell, P. B., Singh, H. B., Thompson, A. M., Shaw, G. E., McCauley, E., Pederson, J. R., and Fisher, J. A.: The Arctic Research of the Composition of the Troposphere from Aircraft and Satellites (ARCTAS) mission: design, execution, and first results, Atmos. Chem. Phys., 10, 5191-5212, doi:10.5194/acp-10-5191-2010, 2010.

Jacobson, M. Z.: Strong radiative heating due to the mixing state of black carbon in atmospheric aerosols, Nature, 409, 695-697, 2001.

Jacobson, M. Z.: Reply to comment by J. Feichter et al. on "Control of fossil-fuel particulate black carbon and organic matter, possibly the most effective method of slowing global warming", J. Geophys. Res., 108, 4768, doi:10.1029/2002JD003299, 2003.

Jacobson, M. Z.: Climate response of fossil fuel and biofuel soot, accounting for soot's feedback to snow and sea ice albedo and emissivity, J. Geophys. Res., 109, D21201, doi:10.1029/2004JD004945, 2004.

Jiao, C., Flanner, M. G., Balkanski, Y., Bauer, S. E., Bellouin, N., Berntsen, T. K., Bian, H., Carslaw, K. S., Chin, M., De Luca, N., Diehl, T., Ghan, S. J., Iversen, T., Kirkevåg, A., Koch, D., Liu, X., Mann, G. W., Penner, J. E., Pitari, G., Schulz, M., Seland, Ø., Skeie, R. B., Steenrod, S. D., Stier, P., Takemura, T., Tsigaridis, K., van Noije, T., Yun, Y., and Zhang, K.: An AeroCom assessment of black carbon in Arctic snow and sea ice, Atmos. Chem. Phys., 14, 2399-2417, doi:10.5194/acp-14-2399-2014, 2014.

Kinne, S., Schulz, M., Textor, C., Guibert, S., Balkanski, Y., Bauer, S. E., Berntsen, T., Berglen, T. F., Boucher, O., Chin, M., Collins, W., Dentener, F., Diehl, T., Easter, R., Feichter, J., Fillmore, D., Ghan, S., Ginoux, P., Gong, S., Grini, A., Hendricks, J., Herzog,
M., Horowitz, L., Isaksen, I., Iversen, T., Kirkevåg, A., Kloster, S., Koch, D., Kristjansson, J. E., Krol, M., Lauer, A., Lamarque, J. F., Lesins, G., Liu, X., Lohmann, U., Montanaro, V., Myhre, G., Penner, J., Pitari, G., Reddy, S., Seland, O., Stier, P., Takemura, T., and Tie, X.: An AeroCom initial assessment - optical properties in aerosol component modules of global models, Atmos. Chem. Phys., 6, 1815-1834, doi:10.5194/acp-6-1815-2006, 2006.

Kipling, Z., Stier, P., Schwarz, J. P., Perring, A. E., Spackman, J. R., Mann, G. W., Johnson, C. E., and Telford, P. J.: Constraints on aerosol processes in climate models from vertically-resolved aircraft observations of black carbon, Atmos. Chem. Phys., 13, 5969-5986, doi:10.5194/acp-13-5969-2013, 2013.

Koch, D., Schulz, M., Kinne, S., McNaughton, C., Spackman, J. R., Balkanski, Y., Bauer, S., Berntsen, T., Bond, T. C., Boucher, O., Chin, M., Clarke, A., De Luca, N., Dentener, F., Diehl, T., Dubovik, O., Easter, R., Fahey, D. W., Feichter, J., Fillmore, D., Freitag, S., Ghan, S., Ginoux, P., Gong, S., Horowitz, L., Iversen, T., Kirkevåg, A., Klimont, Z., Kondo, Y., Krol, M., Liu, X., Miller, R., Montanaro, V., Moteki, N., Myhre, G., Penner, J. E., Perlwitz, J., Pitari, G., Reddy, S., Sahu, L., Sakamoto, H., Schuster, G., Schwarz, J. P., Seland, Ø., Stier, P., Takegawa, N., Takemura, T., Textor, C., van Aardenne, J. A., and Zhao, Y.: Evaluation of black carbon estimations in global aerosol models, Atmos. Chem. Phys., 9, 9001-9026, doi:10.5194/acp-9-9001-2009, 2009.

Lamarque, J.-F., Bond, T. C., Eyring, V., Granier, C., Heil, A., Klimont, Z., Lee, D., Liousse, C., Mieville, A., Owen, B., Schultz, M. G., Shindell, D., Smith, S. J., Stehfest, E., Van Aardenne, J., Cooper, O. R., Kainuma, M., Mahowald, N., McConnell, J. R., Naik, V., Riahi, K., and van Vuuren, D. P.: Historical (1850-2000) gridded anthropogenic and biomass burning emissions of reactive gases and aerosols: methodology and application, Atmos. Chem. Phys., 10, 7017-7039, doi:10.5194/acp10-7017-2010, 2010.

Liu, J., Fan, S., Horowitz, L. W., and Levy, H.: Evaluation of factors controlling long-range transport of black carbon to the Arctic, J. Geophys. Res., 116, D04307, doi:10.1029/2010JD015145, 2011.

Liu, X. and Penner, J. E.: Ice nucleation parameterization for global models, Meteorol. Z., 14, 499-514, 2005.

Liu, X. and Wang, J.: How important is organic aerosol hygroscopicity to aerosol indirect forcing? Environ. Res. Lett., 5, 044010, doi:10.1088/1748-9326/5/4/044010, 2010.

Liu, X., Penner, J. E., and Herzog, M.: Global simulation of aerosol dynamics: Model description, evaluation, and interactions between sulfate and nonsulfate aerosols, J. Geophys. Res., 110, D18206, doi:10.1029/2004JD005674, 2005.

Liu, X., Penner, J. E., Ghan, S. J., and Wang, M.: Inclusion of ice microphysics in the NCAR Community Atmospheric Model version 3 (CAM3), J. Climate, 20, 4526-4547, 2007.

Liu, X., Easter, R. C., Ghan, S. J., Zaveri, R., Rasch, P., Shi, X., Lamarque, J.-F., Gettelman, A., Morrison, H., Vitt, F., Conley, A., Park, S., Neale, R., Hannay, C., Ekman, A. M. L., Hess, P., Mahowald, N., Collins, W., Iacono, M. J., Bretherton, C. S., Flanner, M. G., and Mitchell, D.: Toward a minimal representation of aerosols in climate models: description and evaluation in the Community Atmosphere Model CAM5, Geosci. Model Dev., 5, 709-739, doi:10.5194/gmd-5-709-2012, 2012. 
Ma, P.-L., Rasch, P. J., Wang, H., Zhang, K., Easter, R. C., Tilmes, S., Fast, J. D., Liu, X., Yoon, J.-H., and Lamarque, J.-F.: The role of circulation features on black carbon transport into the Arctic in the Community Atmosphere Model version 5 (CAM5), J. Geophys. Res., 118, 4657-4669, doi:10.1002/jgrd.50411, $2013 \mathrm{a}$.

Ma, P.-L., Gattiker, J. R., Liu, X., and Rasch, P. J.: A novel approach for determining source-receptor relationships in model simulations: a case study of black carbon transport in northern hemisphere winter, Environ. Res. Lett.,8, 024042, doi:10.1088/17489326/8/2/024042, 2013b.

Ma, P.-L., Rasch, P. J., Fast, J. D., Easter, R. C., Gustafson Jr., W. I., Liu, X., Ghan, S. J., and Singh, B.: Assessing the CAM5 physics suite in the WRF-Chem model: implementation, resolution sensitivity, and a first evaluation for a regional case study, Geosci. Model Dev., 7, 755-778, doi:10.5194/gmd-7-755-2014, 2014.

Ma, P.-L., Rasch, P. J., Wang, M., Wang, H., Ghan, S. J., Easter, R. C., Gustafson Jr., W. I., Liu, X., Zhang, Y., and Ma, H.-Y.: How does increasing horizontal resolution in a global climate model improve the simulation of aerosol-cloud interactions?, Geophy. Res. Lett., 42, 5058-5065, doi:10.1002/2015GL064183, 2015.

McNaughton, C. S., Clarke, A. D., Kapustin, V., Shinozuka, Y., Howell, S. G., Anderson, B. E., Winstead, E., Dibb, J., Scheuer, E., Cohen, R. C., Wooldridge, P., Perring, A., Huey, L. G., Kim, S., Jimenez, J. L., Dunlea, E. J., DeCarlo, P. F., Wennberg, P. O., Crounse, J. D., Weinheimer, A. J., and Flocke, F.: Observations of heterogeneous reactions between Asian pollution and mineral dust over the Eastern North Pacific during INTEX-B, Atmos. Chem. Phys., 9, 8283-8308, doi:10.5194/acp-9-8283-2009, 2009.

Morrison, H. and Gettelman, A.: A new two-moment bulk stratiform cloud microphysics scheme in the community atmosphere model, version 3 (CAM3). Part I: Description and numerical tests, J. Climate, 21, 3642-3659, doi:10.1175/2008jcli2105.1, 2008

Myhre, G., Shindell, D., Bréon, F.-M., Collins, W., Fuglestvedt, J., Huang, J., Koch, D., Lamarque, J.-F., Lee, D., Mendoza, B., Nakajima, T., Robock, A., Stephens, G., Takemura, T., and Zhang, H.: Anthropogenic and natural radiative forcing, in: Climate Change 2013: The Physical Science Basis, Contribution of Working Group I to the Fifth Assessment Report of the Intergovernmental Panel on Climate Change, Cambridge University Press, Cambridge, UK, New York, NY, USA, 659-740, 2013.

Neale, R. B., Richter, J. H., and Jochum, M.: The impact of convection on ENSO: From a delayed oscillator to a series of events, J. Climate, 21, 5904-5924, doi:10.1175/2008jcli2244.1, 2008.

Neale, R. B., Chen, C.-C., Gettelman, A., Lauritzen, P. H., Park, S., Williamson, D. L., Conley, A. J., Garcia, R., Kinnison, D., Lamarque, J.-F., Marsh, D., Mills, M., Smith, A. K., Tilmes, S., Vitt, F., Cameron-Smith, P., Collins,W. D., Iacono, M. J., Easter, R. C., Ghan, S. J., Liu, X., Rasch, P. J., and Taylor, M. A.: Description of the NCAR Community Atmosphere Model (CAM 5.0), NCAR/TN-486+ STR, available at: http://www.cesm.ucar.edu/models/cesm1.0/ cam/docs/description/cam5_desc.pdf, 2012.

Park, S. and Bretherton, C. S.: The University of Washington Shallow Convection and Moist Turbulence Schemes and Their Impact on Climate Simulations with the Community Atmosphere Model, J. Climate, 22, 3449-3469, doi:10.1175/2008jcli2557.1, 2009.
Park, S., Bretherton, C. S., and Rasch, P. J.: Integrating cloud processes in the Community Atmosphere Model, Version 5, J. Climate, 27, 6821-6856, doi:10.1175/JCLI-D-14-00087.1, 2014.

Quaas, J., Ming, Y., Menon, S., Takemura, T., Wang, M., Penner, J. E., Gettelman, A., Lohmann, U., Bellouin, N., Boucher, O., Sayer, A. M., Thomas, G. E., McComiskey, A., Feingold, G., Hoose, C., Kristjánsson, J. E., Liu, X., Balkanski, Y., Donner, L. J., Ginoux, P. A., Stier, P., Grandey, B., Feichter, J., Sednev, I., Bauer, S. E., Koch, D., Grainger, R. G., Kirkevåg, A., Iversen, T., Seland, Ø., Easter, R., Ghan, S. J., Rasch, P. J., Morrison, H., Lamarque, J.-F., Iacono, M. J., Kinne, S., and Schulz, M.: Aerosol indirect effects - general circulation model intercomparison and evaluation with satellite data, Atmos. Chem. Phys., 9, 8697-8717, doi:10.5194/acp-9-8697-2009, 2009.

Richter, J. H. and Rasch, P. J.: Effects of convective momentum transport on the atmospheric circulation in the community atmosphere model, version 3, J. Climate, 21, 1487-1499, doi:10.1175/2007jcli1789.1, 2008.

Riemer, N., West, M., Zaveri, R. A., and Easter, R. C.: Simulating the evolution of soot mixing state with a particleresolved aerosol model, J. Geophys. Res., 114, D09202, doi:10.1029/2008JD011073, 2009.

Samset, B. H., Myhre, G., Herber, A., Kondo, Y., Li, S.-M., Moteki, N., Koike, M., Oshima, N., Schwarz, J. P., Balkanski, Y., Bauer, S. E., Bellouin, N., Berntsen, T. K., Bian, H., Chin, M., Diehl, T., Easter, R. C., Ghan, S. J., Iversen, T., Kirkevåg, A., Lamarque, J.-F., Lin, G., Liu, X., Penner, J. E., Schulz, M., Seland, Ø., Skeie, R. B., Stier, P., Takemura, T., Tsigaridis, K., and Zhang, K.: Modelled black carbon radiative forcing and atmospheric lifetime in AeroCom Phase II constrained by aircraft observations, Atmos. Chem. Phys., 14, 12465-12477, doi:10.5194/acp14-12465-2014, 2014.

Schwarz, J. P., Gao, R. S., Fahey, D. W., Thomson, D. S., Watts, L. A., Wilson, J. C., Reeves, J. M., Darbeheshti, M., Baumgardner, D. G., Kok, G. L., Chung, S. H., Schulz, M., Hendricks, J., Lauer, A., Kaercher, B., Slowik, J. G., Rosenlof, K. H., Thompson, T. L., Langford, A. O., Loewenstein, M., and Aikin, K. C.: Single-particle measurements of midlatitude black carbon and light-scattering aerosols from the boundary layer to the lower stratosphere, J. Geophys. Res., 111, D16207, doi:10.1029/2006JD007076, 2006.

Schwarz, J. P., Spackman, J. R., Gao, R. S., Watts, L. A., Stier, P., Schulz, M., Davis, S. M., Wofsy, S. C., and Fahey, D. W.: Global-scale black carbon profiles observed in the remote atmosphere and compared to models, Geophys. Res. Lett., 37, L18812, doi:10.1029/2010GL044372, 2010.

Schwarz, J. P., Samset, B. H., Perring, A. E., Spackman, J. R., Gao, R. S., Stier, P., Schulz, M., Moore, F. L., Ray, E. A., and Fahey, D. W.: Global-scale seasonally resolved black carbon vertical profiles over the Pacific, Geophys. Res. Lett., 40, 5542-5547, doi:10.1002/2013GL057775, 2013.

Schulz, M., Textor, C., Kinne, S., Balkanski, Y., Bauer, S., Berntsen, T., Berglen, T., Boucher, O., Dentener, F., Guibert, S., Isaksen, I. S. A., Iversen, T., Koch, D., Kirkevåg, A., Liu, X., Montanaro, V., Myhre, G., Penner, J. E., Pitari, G., Reddy, S., Seland, Ø., Stier, P., and Takemura, T.: Radiative forcing by aerosols as derived from the AeroCom present-day and pre-industrial simulations, Atmos. Chem. Phys., 6, 5225-5246, doi:10.5194/acp-65225-2006, 2006. 
Spracklen, D. V., Pringle, K. J., Carslaw, K. S., Chipperfield, M. P., and Mann, G. W.: A global off-line model of size-resolved aerosol microphysics: II. Identification of key uncertainties, Atmos. Chem. Phys., 5, 3233-3250, doi:10.5194/acp-5-3233-2005, 2005.

Stier, P., Feichter, J., Kinne, S., Kloster, S., Vignati, E., Wilson, J., Ganzeveld, L., Tegen, I., Werner, M., Balkanski, Y., Schulz, M., Boucher, O., Minikin, A., and Petzold, A.: The aerosol-climate model ECHAM5-HAM, Atmos. Chem. Phys., 5, 1125-1156, doi:10.5194/acp-5-1125-2005, 2005.

Stohl, A., Klimont, Z., Eckhardt, S., Kupiainen, K., Shevchenko, V. P., Kopeikin, V. M., and Novigatsky, A. N.: Black carbon in the Arctic: the underestimated role of gas flaring and residential combustion emissions, Atmos. Chem. Phys., 13, 8833-8855, doi:10.5194/acp-13-8833-2013, 2013.

Textor, C., Schulz, M., Guibert, S., Kinne, S., Balkanski, Y., Bauer, S., Berntsen, T., Berglen, T., Boucher, O., Chin, M., Dentener, F., Diehl, T., Easter, R., Feichter, H., Fillmore, D., Ghan, S., Ginoux, P., Gong, S., Grini, A., Hendricks, J., Horowitz, L., Huang, P., Isaksen, I., Iversen, I., Kloster, S., Koch, D., Kirkevåg, A., Kristjansson, J. E., Krol, M., Lauer, A., Lamarque, J. F., Liu, X., Montanaro, V., Myhre, G., Penner, J., Pitari, G., Reddy, S., Seland, $\varnothing$., Stier, P., Takemura, T., and Tie, X.: Analysis and quantification of the diversities of aerosol life cycles within AeroCom, Atmos. Chem. Phys., 6, 1777-1813, doi:10.5194/acp-6-1777-2006, 2006.

Tie, X., Madronich, S., Walters, S., Edwards, D. P., Ginoux, P., Mahowald, N., Zhang, R., Lou, C., and Brasseur, G.: Assessment of the global impact of aerosols on tropospheric oxidants, J. Geophys. Res., 110, D03204, doi:10.1029/2004JD005359, 2005.
Tilmes, S., Lamarque, J.-F., Emmons, L. K., Kinnison, D. E., Ma, P.-L., Liu, X., Ghan, S., Bardeen, C., Arnold, S., Deeter, M., Vitt, F., Ryerson, T., Elkins, J. W., Moore, F., Spackman, J. R., and Val Martin, M.: Description and evaluation of tropospheric chemistry and aerosols in the Community Earth System Model (CESM1.2), Geosci. Model Dev., 8, 1395-1426, doi:10.5194/gmd-8-13952015, 2015.

Wang, H., Easter, R. C., Rasch, P. J., Wang, M., Liu, X., Ghan, S. J., Qian, Y., Yoon, J.-H., Ma, P.-L., and Vinoj, V.: Sensitivity of remote aerosol distributions to representation of cloud-aerosol interactions in a global climate model, Geosci. Model Dev., 6, 765-782, doi:10.5194/gmd-6-765-2013, 2013.

Wang, M., Ghan, S., Easter, R., Ovchinnikov, M., Liu, X., Kassianov, E., Qian, Y., Gustafson Jr., W. I., Larson, V. E., Schanen, D. P., Khairoutdinov, M., and Morrison, H.: The multiscale aerosol-climate model PNNL-MMF: model description and evaluation, Geosci. Model Dev., 4, 137-168, doi:10.5194/gmd-4137-2011, 2011.

Wofsy, S. C. and the HIPPO team: HIAPER Pole-to-Pole Observations (HIPPO): fine-grained, global-scale measurements of climatically important atmospheric gases and aerosols, Philos. T. Ser. A, 369, 207-386, doi:10.1098/rsta.2010.0313, 2011.

Zhang, G. J. and McFarlane, N. A.: Sensitivity of Climate Simulations to the Parameterization of Cumulus Convection in the Canadian Climate Center General-Circulation Model, Atmos. Ocean, 33, 407-446, 1995. 